\title{
Enhanced Anti-Bacterial Activity Of Biogenic Silver Nanoparticles Synthesized From Terminalia mantaly Extracts
}

This article was published in the following Dove Press journal: International Journal of Nanomedicine

\author{
Michele Stella Majoumouo (D) ${ }^{1,2}$ \\ Nicole Remaliah Samantha \\ Sibuyi $\mathbb{D D}^{2}$ \\ Marius Belmondo Tincho $\mathbb{D}^{2}$ \\ Michele Mbekou' \\ Fabrice Fekam Boyom (D) \\ Mervin Meyer (D) ${ }^{2}$
}

'Antimicrobial \& Biocontrol Agents Unit, Laboratory for Phytobiochemistry and Medicinal Plants Studies, Department of Biochemistry, University of Yaoundé I, Yaoundé, Cameroon; ${ }^{2}$ Department of Science and Technology (DST)/Mintek Nanotechnology Innovation Centre, Biolabels Node, Department of Biotechnology, University of the Western Cape, Bellville, South Africa
Correspondence: Mervin Meyer University of the Western Cape, Department of Biotechnology, New Life Science Building, Robert Sobukwe Road, Bellville 7535, South Africa

Tel +27219592032

Fax +27 21 9593505

Email memeyer@uwc.ac.za
Background: The global increase in outbreaks and mortality rates associated with multidrug-resistant (MDR) bacteria is a major health concern and calls for alternative treatments. Natural-derived products have shown potential in combating the most dreadful diseases, and therefore serve as an effective source of bioactive compounds that can be used as antibacterial agents. These compounds are able to reduce metal ions and cap nanoparticles to form biogenic nanoparticles (NPs) with remarkable anti-bacterial activities. This study explores the use of Terminalia mantaly (TM) extracts for the synthesis of biogenic silver NPs (TM-AgNPs) and the evaluation of their antibacterial activity.

Methods: TM-AgNPs were synthetized by the reduction of $\mathrm{AgNO}_{3}$ with aqueous and methanolic TM extracts. UV-visible (UV-vis) spectrophotometry, Dynamic Light Scattering (DLS), Transmission Electron Microscopy, and Fourier Transform Infrared (FTIR) analyses were used to characterise the TM-AgNPs. Anti-bacterial activity of the TM extracts and TM-AgNPs was evaluated against eight bacterial strains using the broth microdilution assay. The growth inhibitory kinetics of the bio-active TM-AgNPs was assessed on susceptible strains for a period of $8 \mathrm{hrs}$.

Results: Polycrystalline biogenic AgNPs with anisotropic shapes and diameter range of 11 to $83 \mathrm{~nm}$ were synthesized from the TM extracts. The biogenic TM-AgNPs showed significant antibacterial activity compared to their respective extracts. The MIC values for TMAgNPs and extracts were 3 and $125 \mu \mathrm{g} / \mathrm{mL}$, respectively. Biogenic AgNPs synthesised from the aqueous $\mathrm{TM}$ leaf extract at $25^{\circ} \mathrm{C}\left({ }_{\mathrm{a}} \mathrm{TML}-\mathrm{AgNPs}-25^{\circ} \mathrm{C}\right)$ showed significant antibacterial activity against all the bacterial strains tested in this study. Their bactericidal effect was particularly higher against the Streptococcus pneumoniae and Haemophilus influenzae.

Conclusion: This study demonstrated the ability of TM extracts to synthesize biogenic AgNPs. The NPs synthesized from the aqueous TM extracts demonstrated higher antibacterial activity against the tested microorganisms compared to the methanolic extracts. Studies are underway to identify the phytochemicals involved in NP synthesis and their mechanism of action.

Keywords: antimicrobial resistance, green synthesis, nanotechnology, Terminalia mantaly, antibacterial activity

\section{Introduction}

Antimicrobial resistance (AMR) is increasingly recognized as a growing global health problem and accounts for over 700,000 deaths annually. ${ }^{2}$ AMR following bacterial infections in particular, is a major concern due to their high prevalence and mortality rates in both developed and developing countries. ${ }^{1}$ Europe and the United States of America (USA) have been reported to have high rates of AM-resistant bacterial infections and associated mortality rates. More than 20,000 people in 
Europe and the USA succumb to antibiotic-resistant bacterial infections per annum. ${ }^{2}$ Thus, the problems associated with the rise of multi-drug-resistant (MDR) bacterial infections have prompted a need for novel and cost-effective antimicrobial agents. ${ }^{3-5}$ Recent advancements in nanotechnology-based medicines have opened new horizons for developing strategies that can combat AMR. Silver nanoparticles (AgNPs) have shown excellent bactericidal properties against a range of microorganisms, including the most problematic antibiotic-resistant strains such as Bacillus subtilis, Escherichia coli, Neisseria gonorrhoeae, Pseudomonas aeruginosa, Staphylococcus aureus and Streptococcus faecalis. ${ }^{6,7}$

NPs compared to their bulk counterparts have unique properties attributed to their small size, which can increase the efficacy and bioavailability of antimicrobial agents. ${ }^{89}$ A variety of protocols for the synthesis of different geometric shapes and sizes of AgNPs have been reported. ${ }^{10,11}$ However, most of the protocols involve the use of toxic chemicals as reducing and capping agents which are likely to produce toxic byproducts. The by-products might have adverse effects on human health and the environment. ${ }^{10,11}$ Conversely, green biosynthetic methods that use natural products as both reducing and capping agents have emerged as alternative synthesis routes. The green synthesis of nanomaterials has generated a great interest as it provides a simple, cost-effective, readily scalable, and eco-friendly products with minimal toxicity towards human beings. ${ }^{12-15}$ Natural products are used extensively as reducing as well as capping agents to prevent the agglomeration and increase the stability of the synthesized NPs. ${ }^{16-18}$ The synthesis of AgNPs of different shapes and sizes using various plants extracts has been reported. ${ }^{19-21}$ Such biogenic AgNPs demonstrated enhanced antibacterial activity on a wide spectrum of multi drug-resistant grampositive and -negative bacterial pathogens. ${ }^{22-25}$ The precise mechanism of antibacterial activity of AgNPs is not fully understood. ${ }^{20}$ It is speculated that their small size could increase oxidative stress in the cells by generating reactive oxygen species or attacking the fatty acids in the cell membranes resulting in increased lipid peroxidation. ${ }^{26} \mathrm{AgNPs}$ once inside the bacterial cells, destabilizes the intracellular structures and biomolecules, consequently inducing death. ${ }^{27,28}$

The current study reports on the synthesis of AgNPs using aqueous and methanolic extracts of the Terminalia mantaly (TM) plant. The study also investigates the antibacterial activity of TM extracts and AgNPs. Extracts from Terminalia species (Combretaceae) such as Terminalia catappa, Terminalia bellerica, Terminalia bentazoe, Terminalia mellueri, Terminalia arjuna and Terminalia cheduba have been widely used by traditional healers to treat diseases such as cancer, dysentery, diabetes, mycosis and bacterial infections. ${ }^{19,29}$ Terminalia extracts are commonly rich in phenolics, flavonoids, alkaloids, triterpenoids, and tannins. ${ }^{30,31}$ These phytochemicals can potentially be used as reducing agents in the synthesis of colloidal gold and silver metallic NPs. Previous studies have shown that TM extracts can inhibit the growth of a wide range of pathogenic bacteria. ${ }^{32,33}$ Moreover, silver and gold NPs synthesized from Terminalia species namely Terminalia cheduba, ${ }^{34}$ Terminalia catappa, Terminalia mellueri, Terminalia bentazoe and Terminalia bellerica ${ }^{19}$ have demonstrated a wide range of biological activities such as antibacterial, antioxidant and anti-inflammatory proprieties. ${ }^{19,34}$ To the best of our knowledge, this will be the first study to demonstrate the biosynthesis and antibacterial activity of AgNPs produced from TM extracts.

\section{Materials And Methods}

\section{TM Sample Collection And Identification}

The TM plant materials were collected from Yaoundé (Cameroon, West Africa). Fresh leaves (TML), stem bark (TMSB) and roots (TMR) were harvested from mature TM plants. The identity of the plant was confirmed at the National Herbarium (Yaoundé, Cameroon), the reference number of the herbarium sample is $64,212 / \mathrm{HNC}$.

\section{TM Samples Preparation And Extraction}

The plant material was washed with distilled water, cut into small pieces and dried at room temperature $\left(25^{\circ} \mathrm{C}\right)$ in the dark. The dried samples were ground into powder using industrial food grinders. The samples were stored in a desiccator at room temperature until further processing.

The aqueous and methanolic TM extracts denoted by ${ }_{\mathrm{a}} \mathrm{TM}$ and ${ }_{\mathrm{m}} \mathrm{TM}$, respectively, were obtained by maceration procedure. Briefly, $100 \mathrm{~g}$ fine powder of TML, TMSB and TMR samples were soaked in $1 \mathrm{~L}$ of either methanol (for $48 \mathrm{hrs)} \mathrm{or}$ sterile distilled water (for $72 \mathrm{hrs)} \mathrm{at} \mathrm{room} \mathrm{temperature.} \mathrm{The}$ extraction procedure was repeated three times and filtered using Whatman No 1 filter paper. The methanolic filtrates were evaporated to dryness using a rotary evaporator (Büchi 011, Flawil, Switzerland). The aqueous filtrates were lyophilized using a Martin Christ Beta 2-8 lyophilizer (Germany). The extracts were stored at $4^{\circ} \mathrm{C}$. 


\section{Green Synthesis Of AgNPs Using TM Extracts}

The optimal conditions for the synthesis of the AgNPs were obtained using a previously reported method. ${ }^{35}$ Stock concentrations $(50 \mathrm{mg} / \mathrm{mL})$ of the aqueous and methanolic extracts were prepared in distilled water. Small-scale synthesis was carried out in a 96 well plate to obtain the optimal concentration of TM extracts and temperature. Briefly, $50 \mu \mathrm{L}$ of $_{\mathrm{a}} \mathrm{TM}$ or ${ }_{\mathrm{m}} \mathrm{TM}$ extracts (at concentrations ranging from 0.78 to $50 \mathrm{mg} / \mathrm{mL}$ ) were placed in a 96 well plate and $250 \mu \mathrm{L}$ of 3 $\mathrm{mM} \mathrm{AgNO}_{3}$ was added to the plant extracts. The samples were prepared in duplicate plates. One plate was incubated at $25^{\circ} \mathrm{C}$ and a second plate at $70^{\circ} \mathrm{C}$, while shaking at $40 \mathrm{rpm}$ for $24 \mathrm{hrs}$. The optimum concentration of extracts was used to scale up the AgNP synthesis from $300 \mu \mathrm{L}$ to $2 \mathrm{~mL}$. The AgNPs were recovered by centrifuged at 14,000 rpm for 10 $\mathrm{min}$. The AgNPs were washed with sterile distilled water to remove excess $\mathrm{AgNO}_{3}$ and plant extract. The TM-AgNPs were re-suspended in sterile distilled water and stored at $4^{\circ} \mathrm{C}$.

\section{Characterization Of TM-AgNPs} UV-Vis Spectrophotometry And DLS Analysis

UV-vis analysis (350-700 nm) of the TM-AgNPs was performed using a POLAR star Omega microplate reader (BMG Labtech, Germany). The hydrodynamic diameter, polydispersity index (Pdi) and zeta potential of the synthesized TMAgNPs were analysed by DLS using a Malvern Nano ZS90 Zetasizer (Malvern, UK).

\section{HRTEM Characterization Of TM-AgNPs}

The morphology, core size, and the crystallinity of the TMAgNPs were characterized by High-Resolution Transmission Election Microscopy (HRTEM) using a FEI Tecnai G2 20 field-emission HRTEM (Oregon, OR, USA). HRTEM was also used for Energy Dispersive X-ray (EDX) and Selected Area Electron Diffraction (SAED) analysis. The samples were prepared by drop-coating one drop of each sample onto a carbon-coated copper grid. The samples were dried under a Xenon lamp for $10 \mathrm{~min}$ and analysed by HRTEM. Transmission electron micrographs were captured in bright field mode at an accelerating voltage of $200 \mathrm{KeV}$. EDX spectra were collected using an EDX liquid nitrogen cooled Lithium doped Silicon detector. The TEM micrographs were analysed using Image J Software (50b version 1.8.0_60, http://imagej. $\underline{\text { nih.gov/ij). }}$

\section{FTIR Analysis Of TM-AgNPs}

FTIR analysis of the TM-AgNPs and extracts was performed using a JASCO 460 plus spectrophotometer (Perkin Elmer, Massachusetts, MA, USA) with a frequency ranging from 4,000 to $400 \mathrm{~cm}^{-1}$. The TM-AgNPs were dried in an oven at $70^{\circ} \mathrm{C}$. The TM extracts and AgNPs powders were mixed with potassium bromide $(\mathrm{KBr})$ powder and pressed into a pellet prior to FTIR analysis. Background correction was made using a reference blank $\mathrm{KBr}$ pellet. The baseline corrections were performed for all spectra.

\section{Screening Of Antibacterial Activity Of TM Extracts And AgNPs}

The antibacterial activity of the TM extracts and AgNPs was assessed on eight bacterial strains according to the guidelines set by Clinical Laboratory Standards Institute (M07A9, $2012)^{36}$ with slight modifications. Some of the bacterial strains that are listed in Table 1 were a kind gift from Biodefense and Emerging Infections Research Resources Repository (BEI resources, Rockville, MD 20,852) and some were purchased from the American Type Culture Collection (ATCC, Manassas, VA, USA).

Table I List Of Bacterial Strains Used For Anti-Bacterial Activity

\begin{tabular}{|c|c|c|c|}
\hline Bacterial Strains & Acronym & Reference No. & Supplier \\
\hline Streptococcus pneumoniae & S. pneumoniae & ATCC 49619 & ATCC \\
\hline Klebsiella pneumoniae & K. pneumoniae & ATCC 13883 & ATCC \\
\hline Haemophilus influenzae & H. influenzae & ATCC 49247 & ATCC \\
\hline Shigella flexneri & S. flexneri & NR-5I8 & BEI resources \\
\hline Salmonella enterica & S. enterica ${ }^{a}$ & NR-13555 & BEI resources \\
\hline Salmonella enterica & S. enterica ${ }^{\mathrm{b}}$ & NR-4294 & BEI resources \\
\hline Salmonella enterica enterica & S. enterica enterica & NR-43II & BEI resources \\
\hline Staphylococcus aureus & S. aureus & NR-45003 & BEI resources \\
\hline
\end{tabular}

Notes: S. enterica ${ }^{a}$ (Salmonella enterica subsp. enterica A36 (Serovar Typhimurium) vs S. enterica ${ }^{b}$ (Salmonella enterica subsp. enterica 2004 Pennsylvania Tomato Outbreak, Serovar Anatum, Isolate 4).

Abbreviations: ATCC, American Type Culture Collection; BEl resources, biodefense and emerging infections research resources repository. 
Mueller-Hinton broth (Sigma, MO, USA) was inoculated with single bacterial colonies and the cultures were incubated at $37^{\circ} \mathrm{C}$ with shaking at $400 \mathrm{rpm}$ for $18-24 \mathrm{hrs}$. The bacterial suspensions were subsequently standardized to $0.5 \mathrm{McF}$ arland $\left(\sim 1.5 \times 10^{8}\right.$ cells $\left./ \mathrm{mL}\right)$ at $450 \mathrm{~nm}$. Each inoculum was diluted to a final concentration of $5 \times 10^{5}$ cells $/ \mathrm{mL}$ and further dispensed in a 96 well plate at $100 \mu \mathrm{L}$ per well. Single point inhibitory effect of TM extracts and TM-AgNPs was determined against the eight bacterial strains. To this end, $100 \mu \mathrm{L}$ of ${ }_{\mathrm{a}} \mathrm{TM}(500$ $\mu \mathrm{g} / \mathrm{mL}),{ }_{\mathrm{m}} \mathrm{TM}$ extracts $(500 \mu \mathrm{g} / \mathrm{mL})$ or TM-AgNPs $(12.5$ $\mu \mathrm{g} / \mathrm{mL}$ ) were individually added to wells containing $100 \mu \mathrm{L}$ bacteria and the plates were incubated for $24 \mathrm{hrs}$. Ampicillin was used as the positive control at $128 \mu \mathrm{g} / \mathrm{mL}$. The turbidity of the bacterial culture, which was visually examined, was used as an indication of bacterial growth. Growth inhibition was defined by reduction in the turbidity of the bacterial culture. The susceptibility of the bacterial strains to the TM extracts and TM-AgNPs was expressed as the number of the strains that showed growth inhibition. The percentage of bacterial growth inhibition was calculated according to the following formula:

$\%$ Growth in hibition $=$

$\left(\begin{array}{l}\text { Number of strains in hibited by the test sample/ } \\ \text { Total number of tested strains }\end{array}\right)$ X 100

Dose-Response Studies And Evaluation Of The MIC For Active Extracts And TM-AgNPs

MICs were determined for TM-AgNPs that inhibited bacterial growth by more than $75 \%$ (i.e. the ${ }_{\mathrm{a}} \mathrm{TMSB}-70^{\circ} \mathrm{C}$ and aTML AgNPs $-25^{\circ} \mathrm{C}$ ) using the microdilution assay as described above. The bacteria (S. pneumoniae, K. pneumoniae, H. influenzae, S. flexneri, S. enterica ${ }^{a}$, S. enterica enterica and $S$. aureus) were treated with increasing concentrations of the crude extracts $(0-500 \mu \mathrm{g} / \mathrm{mL})$ and TMAgNPs $(0-12.5 \mu \mathrm{g} / \mathrm{mL})$. The negative (untreated) and positive (treatment with ampicillin at $0-128 \mu \mathrm{g} / \mathrm{mL}$ ) controls were also included. After $24 \mathrm{hrs}$ of treatment, the turbidity of the bacterial suspension was visually assessed as an indication of bacterial growth. The lowest concentration that inhibited the visible growth of bacteria was recorded as the MIC. All the experiments were performed in triplicate.

\section{Bacterial Growth Inhibition Kinetics Of Active TM- AgNPs}

The bacterial growth kinetics following treatment with ${ }_{\mathrm{a}}$ TMSB and ${ }_{\mathrm{a}}$ TML AgNPs was studied using a protocol that was previously published. ${ }^{37,38}$ Briefly, the susceptible bacterial strains were treated with the following concentrations: $1 \times \mathrm{MIC}, 1 / 2 \times \mathrm{MIC}$ and $1 / 4 \times \mathrm{MIC}$ of each AgNPs. Ampicillin was used as a positive control at its MIC value. The assays were performed in triplicate in a 96 well plates. The OD of bacterial cultures was measured at $630 \mathrm{~nm}$ at different time points $(2,3,4,6,7 \mathrm{and} 8 \mathrm{hr})$ to monitor bacterial growth rate, and the growth curves were plotted as absorbance (OD $630 \mathrm{~nm}$ ) versus time (hrs).

\section{Statistical Analysis}

The results were analysed using Graph pad prism 6.0. The data are presented as means \pm SD according to one-way ANOVA test followed by a post hoc multiple comparisons (Tukey's test). A p value of $<0.05$ was considered statistical significance and represented by an asterisk $\left({ }^{*}\right) .{ }^{*} p<0.05,{ }^{* *} \mathrm{p}<0.01,{ }^{* * *} \mathrm{p}$ $<0.001$.

\section{Results And Discussion Physical And UV Vis Analysis Of TM- AgNPs}

The colour of colloidal solutions of AgNPs can vary from yellow-green to blue, depending on the size and morphology of synthesized NPs as demonstrated by Raza et $\mathrm{al}^{39}$. For biogenic AgNPs, the variation in colours is also dependent on the concentration of the extracts and the temperature applied in the synthesis of the AgNPs. ${ }^{38}$ These colour changes have been reported in several studies. ${ }^{40,41}$ Figure 1 shows that the colour of $\mathrm{AgNO}_{3} /$ TM extract mixtures changed to yellow, brown or green. These colour changes observed during the synthesis of AgNPs is one of the first indications that AgNP synthesis was successful. Figure 1 shows that ${ }_{\mathrm{a}} \mathrm{TMR}-\mathrm{AgNP}, \mathrm{m}_{\mathrm{m}} \mathrm{TML}-$ AgNP, ${ }_{m}$ TMSB-AgNP, and ${ }_{m}$ TMR-AgNP produced a yellow colour, while ${ }_{\mathrm{a}}^{\mathrm{T} M L-A g N P}$ produced a green colour and ${ }_{\mathrm{a}} \mathrm{TMSB}-\mathrm{AgNP}$ produced a brown colour.

Due to surface plasmon resonance (SPR), UV-vis spectrophotometric analysis of AgNP that are between 10 and $100 \mathrm{~nm}$ in size typically produces absorbance peaks $(\lambda \max )$ from 400 to $500 \mathrm{~nm}$. As shown in Figure 2 and Table 2, the absorbance peaks of the TM-AgNPs ranged from 438 to $480 \mathrm{~nm}$. This also confirms the presence of AgNPs following the reactions using TM extracts. Flavonoids and phenolic compounds are the major components in the TM extracts. ${ }^{32}$ These phenolic and hydroxylated constituents are most likely responsible for the reduction of $\mathrm{AgNO}_{3}$ to form the AgNP. ${ }^{42}$ The peak intensity of AgNP synthesised at $70^{\circ} \mathrm{C}$ was significantly higher, which suggests that the concentration of the NPs was higher at $70^{\circ} \mathrm{C}$ than at $25^{\circ} \mathrm{C}$. 


\section{Plant collection}

2. Maceration

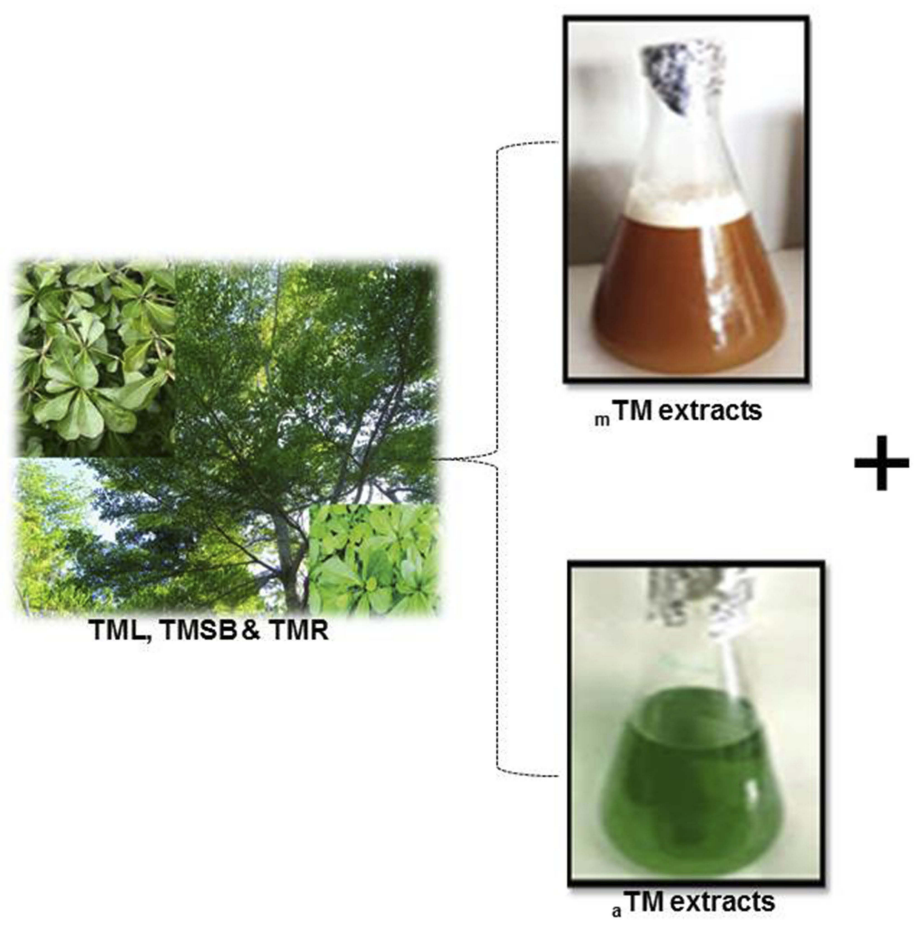

3. Bioreduction

4. NP Synthesis

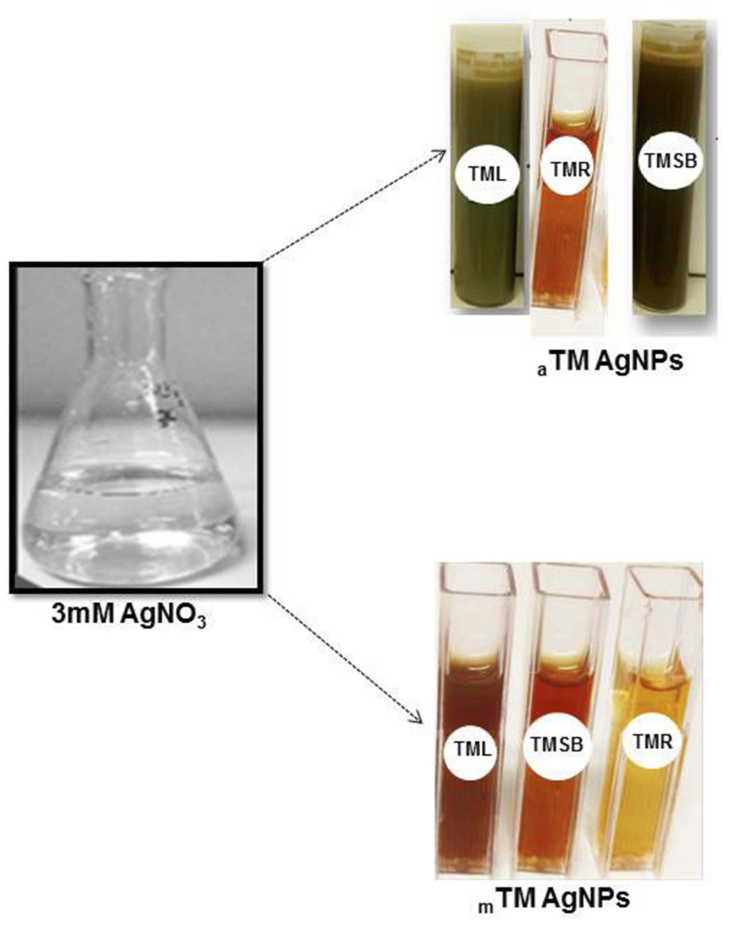

Figure I Schematic representation of the AgNP synthesis from TM plant extracts.

Notes: Aqueous and methanolic TM extracts were used to reduce $\mathrm{AgNO}_{3}$ into $\mathrm{AgNPs}$, color change indicates NP formation.

Abbreviations: AgNPs, silver nanoparticles; TM, Terminalia mantaly; TML, TM leaf extract; TMSB, TM stem bark extract; TMR, TM root extract; TML-AgNPs, AgNPs from TM leaf extract; TMSB-AgNPs, AgNPs from TM stem bark extract; TMR-AgNPs, AgNPs from TM root extract; ${ }_{a}$, aqueous; ${ }_{m}$, methanolic.

In fact, based on UV-vis spectrophotometric analysis, synthesis of ${ }_{\mathrm{m}} \mathrm{TMSB}-\mathrm{AgNP}$ and $\mathrm{m}$ TML-AgNP at $25^{\circ} \mathrm{C}$ was not very successful as the peak intensities for these AgNPs were very low. The absorbance peaks for ${ }_{\mathrm{m}} \mathrm{TMR}-$ AgNP, ${ }_{a}$ TMSB-AgNP and ${ }_{\mathrm{a}} \mathrm{TML}-\mathrm{AgNP}$ (produced at $70^{\circ} \mathrm{C}$ ) were much sharper compared to the absorbance peaks for aTMR-AgNP, ${ }_{m}$ TMSB-AgNP and ${ }_{m}$ TML-AgNP (also produced at $70^{\circ} \mathrm{C}$ ). This suggests that ${ }_{\mathrm{m}} \mathrm{TMR}-\mathrm{AgNP}$, ${ }_{\mathrm{a}}^{\mathrm{T}} \mathrm{TMSB}-$ AgNP and ${ }_{\mathrm{a}} \mathrm{TML}-\mathrm{AgNP}$ are smaller and more uniform than aTMR-AgNP, ${ }_{m}$ TMSB-AgNP and ${ }_{m}$ TML-AgNP.

\section{DLS And FTIR Analyses Of TM-AgNPs}

The hydrodynamic diameter, zeta potential and polydispersity index (Pdi) of the TM-AgNPs were measured by the DLS. As shown in Table 2, the sizes of the TM-AgNPs varied depending on the extract used for the synthesis and temperature $\left(25^{\circ} \mathrm{C}\right.$ versus $70^{\circ} \mathrm{C}$ ) at which synthesis was done. The hydrodynamic diameter of the TM-AgNPs ranged from 11 to $83 \mathrm{~nm}$. The a TML extract produced smaller AgNPs compared to the other extracts. The zeta potential of the synthesized TM-AgNPs ranged from -12 to $-37 \mathrm{mV}$. Zeta potential is an important parameter used to assess the charge of the NP surface and predicts the long-term stability of the NPs. NPs with negative zeta potential values suggest there are strong repulsion forces between the NPs, which will prevent the agglomeration of the NPs in solution. ${ }^{11,43}$ NPs with a zeta potential within the +30 $\mathrm{mV}$ to $-30 \mathrm{mV}$ range are considered to be stable, while those outside this range will likely aggregate due to inter-particle van der Waal's attractions. The aTMSB-AgNPs were the only NPs with zeta potential values outside this range ( -34 and -37 $\mathrm{mV}$ for TM-AgNPs synthesized at $25^{\circ} \mathrm{C}$ and $70^{\circ} \mathrm{C}$, respectively) (Table 2). This suggests that all the TM-AgNPs except for ${ }_{\mathrm{a}}$ TMSB-AgNPs are stable. The Pdi, which is an indication of uniformity, is an important parameter of NPs to consider when assessing the application of NPs, since Pdi can affect the surface conjugation chemistry and NP aggregation. ${ }^{44}$ According to the International Organization for Standardization (ISO), ${ }^{45}$ Pdi values $>0.7$ indicate that the samples have a very broad size distribution, while Pdi values $\leq 0.5$ are more monodispersed. ${ }^{49}$ Based on the Pdi values obtained for ${ }_{\mathrm{a}}^{\mathrm{TML}}$-AgNPs, ${ }_{\mathrm{a}}^{\mathrm{T} M S B}-\mathrm{AgNPs}$, $\mathrm{a}$ TMR-AgNPs and ${ }_{\mathrm{m}} \mathrm{TMR}-\mathrm{AgNPs}$ synthesised at $25^{\circ} \mathrm{C}$, these TM-AgNPs are monodispersed. Similarly, aTML-AgNPs and ${ }_{\mathrm{a}}$ TMSBAgNPs synthesised at $70^{\circ} \mathrm{C}$ are also monodispersed. 
A
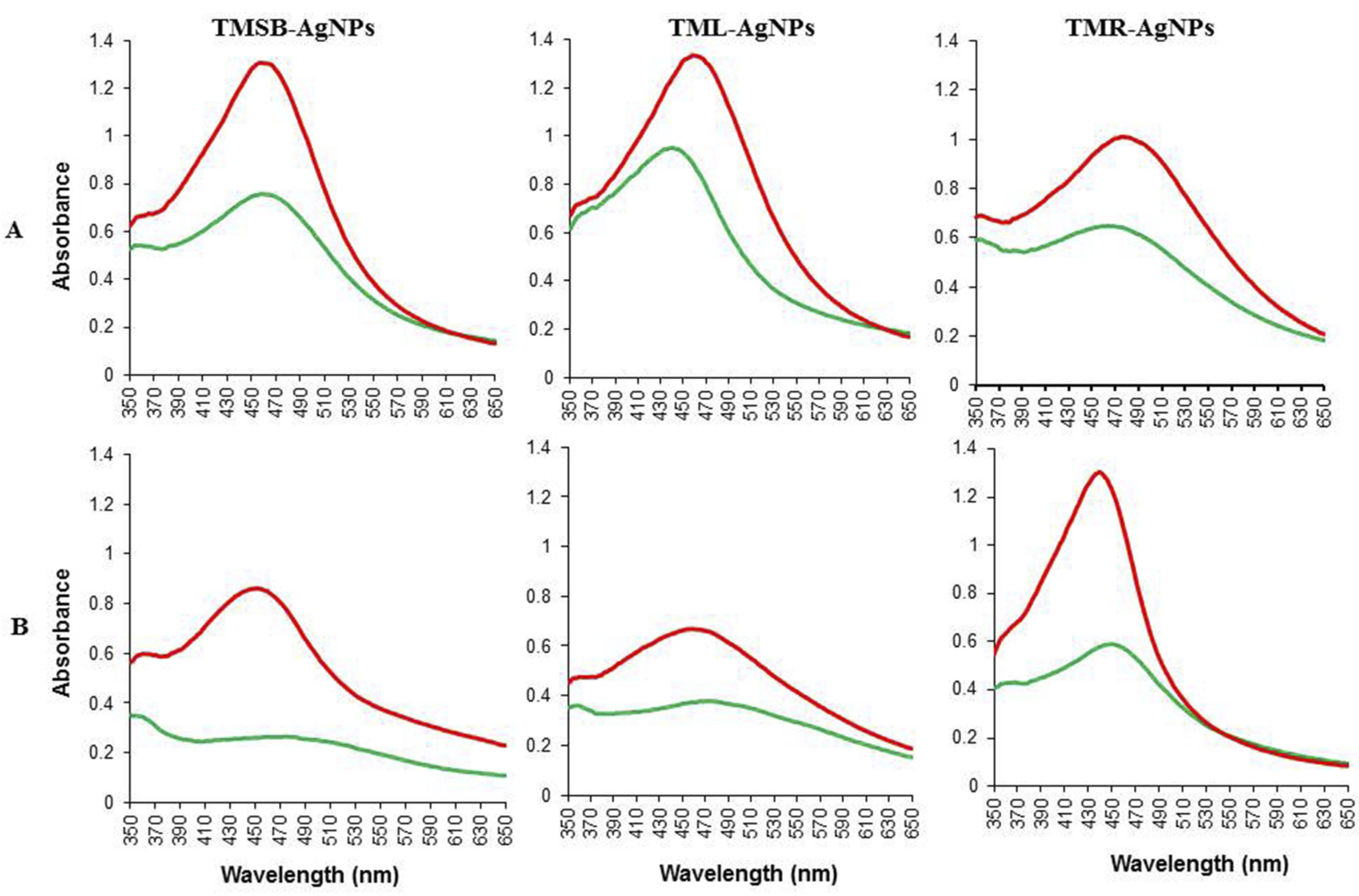

$25^{\circ} \mathrm{C}$

$70^{\circ} \mathrm{C}$

Figure $2 \mathrm{UV}$-vis spectral profiles of TM-AgNPs synthesised at $25^{\circ} \mathrm{C}$ and $70^{\circ} \mathrm{C}$.

Notes: $\mathrm{AgNPs}$ were synthesized by reducing $\mathrm{AgNO}_{3}$ with aqueous $(\mathbf{A})$ and methanolic $(\mathbf{B}) \mathrm{TM}$ extracts. The optical properties of the NPs were measured by UV-vis spectophotometry.

Abbreviations: AgNPs, silver nanoparticles; TM, Terminalia mantaly; TML-AgNPs, AgNPs from TM leaf extract; TMSB-AgNPs, AgNPs from TM stem bark extract; TMRAgNPs, AgNPs from TM root extract.

Various phytochemicals that are present in the plant extracts are expected to play a role in the synthesis of AgNPs. ${ }^{46}$ These phytochemicals are involved in the reduction of $\mathrm{AgNO}_{3}$ and stabilization of the AgNPs. Different chemical classes influence the production of AgNPs, as well as their shape, size and bio-activity. ${ }^{47}$ As

Table 2 SPR And DLS Analysis Of TM-AgNPs Synthesized At $25^{\circ} \mathrm{C}$ And $70^{\circ} \mathrm{C}$

\begin{tabular}{|c|c|c|c|c|c|c|c|c|c|c|}
\hline \multirow[t]{3}{*}{ TM-AgNPs } & \multicolumn{10}{|c|}{ NP Parameters } \\
\hline & \multicolumn{5}{|c|}{$25^{\circ} \mathrm{C}$} & \multicolumn{5}{|c|}{$70^{\circ} \mathrm{C}$} \\
\hline & $\begin{array}{l}\text { [Extract] } \\
(\mathrm{mg} / \mathrm{mL})\end{array}$ & $\lambda \max (\mathrm{nm})$ & PD (nm) & Pdi & ZP $(\mathbf{m V})$ & $\begin{array}{l}\text { [Extract] } \\
(\mathrm{mg} / \mathrm{mL})\end{array}$ & $\lambda \max (\mathrm{nm})$ & PD (nm) & Pdi & ZP $(\mathrm{mV})$ \\
\hline a TML-AgNPs & 0.78 & 438 & II & 0.50 & -24 & 1.56 & 460 & 18 & 0.40 & -26 \\
\hline $\mathrm{m}^{\mathrm{TML}-\mathrm{AgNPs}}$ & 1.56 & 474 & 44 & 0.60 & -22 & 1.56 & 458 & 22 & 0.80 & -29 \\
\hline a TMSB-AgNPs & 0.78 & 464 & 28 & 0.22 & -34 & 1.56 & 460 & 56 & 0.46 & -37 \\
\hline${ }_{m}$ TMSB-AgNPs & 1.56 & 480 & 60 & 0.62 & -12 & 1.56 & 458 & 58 & 0.53 & -12 \\
\hline a TMR-AgNPs & 3.12 & 472 & 39 & 0.40 & -23 & 3.125 & 478 & 30 & 0.88 & -24 \\
\hline${ }_{m}$ TMR-AgNPs & 0.78 & 450 & 83 & 0.48 & -22 & 0.78 & 438 & 67 & 0.51 & -28 \\
\hline
\end{tabular}

Abbreviations: AgNPs, silver nanoparticles; TM, Terminalia mantaly; a, aqueous extracts; $m$, methanolic extracts; TML-AgNPs, AgNPs from TM leaf extracts; TMSB-AgNPs, AgNPs from of TM stem bark extracts; TMR-AgNPs, AgNPs from TM root extracts;SPR, surface plasmon resonance; UV, ultraviolet; PD, particle diameter; ZP, Zeta potential; Pdi, Polydispersity index; DLS, dynamic light scattering. 


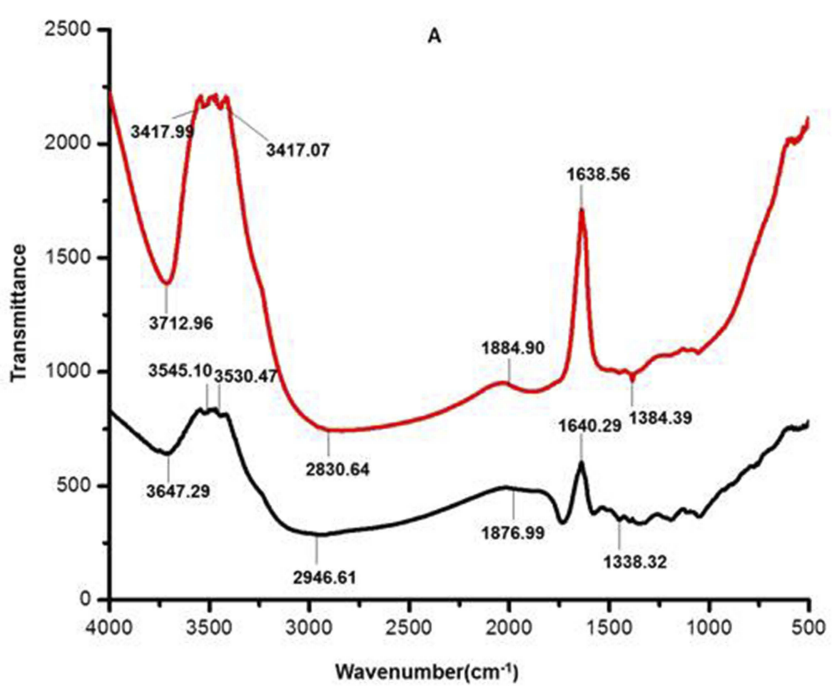

- Extract

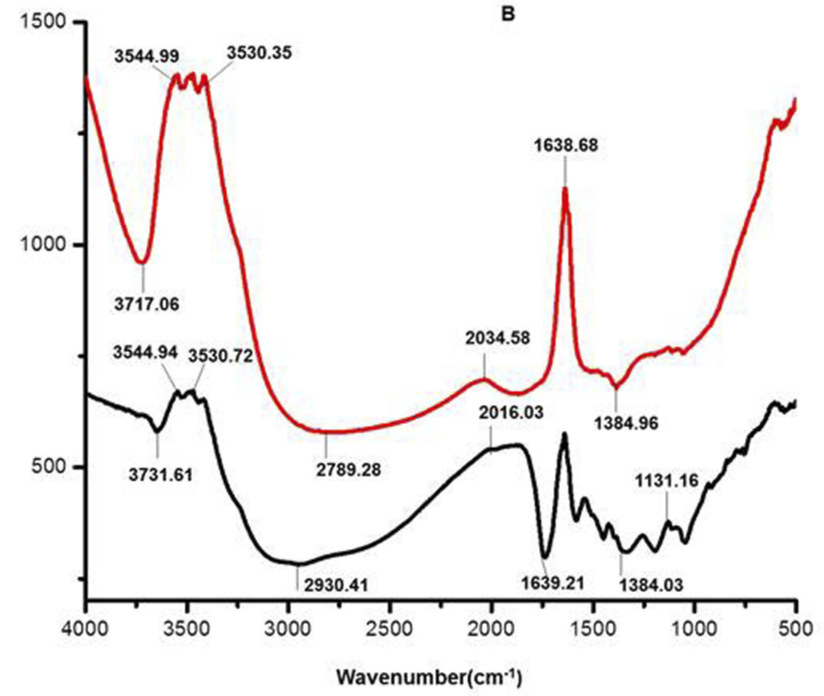

TM-AgNPs

Figure 3 FTIR spectra of selected TM-AgNPs compared to their respective TM extracts.

Notes: FTIR spectra of (A) aTML extract, (B) ${ }_{\mathrm{a}} \mathrm{TML}-\mathrm{AgNPs}$ synthesized at $25^{\circ} \mathrm{C},(\mathbf{C}){ }_{\mathrm{a}} \mathrm{TMSB}$ extract and (D) ${ }_{\mathrm{a}} \mathrm{TMSB}-\mathrm{AgNPs}$ synthesized at $70^{\circ} \mathrm{C}$.

Abbreviations: AgNPs, silver nanoparticles; TM, Terminalia mantaly; ${ }_{\mathrm{a}} \mathrm{TML}$, aqueous TM leaf extract; ${ }_{\mathrm{a}} \mathrm{TMSB}$, aqueous TM stem bark; FTIR, Fourier-transform infrared.

such, it is expected that some of the phytochemicals that are present in the extract will be present on the TMAgNPs. Comparative FTIR spectroscopy analysis between the TM extracts and the accompanying AgNPs was used to demonstrate this (Figure 3). In Figure 3, the FTIR spectrum of ${ }_{\mathrm{a}}^{\mathrm{T} M L-A g N P s}$ synthesized at $25^{\circ} \mathrm{C}$ is compared to the spectrum of the TML extract, while the ${ }_{\mathrm{a}}^{\mathrm{TMSB}}$ AgNPs synthesised at $70^{\circ} \mathrm{C}$ is compared to the ${ }_{a}$ TMSB extract. Several commonalities between the spectra of the extracts and their respective TM-AgNPs could be identified. This suggests that the extracts and their respective TM-AgNPs share similar functional groups, which originate from phytochemicals that were involved in the synthesis of the TM-AgNPs. Shifts in the peak in the FTIR spectra of ${ }_{\mathrm{a}}$ TMSB and ${ }_{\mathrm{a}} \mathrm{TML}$ extracts and their respective AgNPs are summarized in Table 3. In particular, the spectra of ${ }_{\mathrm{a}} \mathrm{TML}$ extract and $\mathrm{AgNPs}$ produced at $25^{\circ} \mathrm{C}$ were characterized by methyl $(\mathrm{C}-\mathrm{H})$ rock alkanes vibration band at 1338.32 and $1384.39 \mathrm{~cm}^{-1}$, and the $\mathrm{C}-\mathrm{H}$ stretching observed between 2946.61 and $2830.64 \mathrm{~cm}^{-1}$. Moreover, there was a $\mathrm{C}=\mathrm{C}$ double-bond stretching at 1640.29 and $1638.56 \mathrm{~cm}^{-1}$. Additionally, strong $\mathrm{OH}$ group vibrations assigned to phenol bands at 3647.29 and $3712.96 \mathrm{~cm}^{-1}$ were detected in both samples (Figure 4A and B).

The FTIR spectra of ${ }_{\mathrm{a}}$ TMSB extract and AgNPs produced at $70^{\circ} \mathrm{C}$ showed fewer similarities between the two samples (Figure $3 \mathrm{C}$ and D). The spectra of ${ }_{\mathrm{a}} \mathrm{TMSB}$ extract revealed intense bands at $1048.80 \mathrm{~cm}^{-1}$ attributed to carbonyls $(\mathrm{C}=\mathrm{O})$ vibrations that were absent on ${ }_{\mathrm{a}} \mathrm{TMSB}-$ AgNPs produced. Some similarities in the two samples were observed; the spectra of ${ }_{\text {a }}$ TMSB extract and AgNPs revealed bands at 1384.03 and 1384.96 corresponding to methyl $(\mathrm{C}-\mathrm{H})$ rock alkanes deformation, 1639.21 and 1638.68 bands attributed to stretch alkenes $(\mathrm{C}=\mathrm{C})$, 2930.41 and 2789.28 bands corresponding to C-H stretching, 3717.06 and 3731.61 intense bands attributed to $\mathrm{O}-\mathrm{H}$ from alcohols and phenols vibrations. The shift in the different functional groups might be caused by the polyphenolics, flavonoids, and terpenoids present in the TM extracts. The same phytochemicals might be responsible for reducing, capping and stabilization of the biogenic AgNPs. ${ }^{13,31,48-50}$ Several studies reported that the active components in the plant extracts such as terpenoids and flavonoids act as reducing agent of the silver precursor to form AgNPs. ${ }^{51}$

\section{HRTEM And EDX Analyses Of Bio-Active TM-AgNPs}

The morphology and size of ${ }_{\mathrm{a}}$ TML-AgNPs and ${ }_{\mathrm{a}}$ TMSBAgNPs varied as demonstrated by the HRTEM micrographs in Figure 4A. The AgNPs displayed heterogeneous and polydispersed characteristics. The ${ }_{\mathrm{a}}^{\mathrm{T} M L}$ produced mostly spherical $\mathrm{AgNPs}$ at $25^{\circ} \mathrm{C}$ whereas the same sample produced various geometric shapes such as triangular, 
Table 3 Comparison FTIR Spectra Of TM Extracts And Their Respective AgNPs

\begin{tabular}{|c|c|c|c|c|c|c|c|}
\hline \multicolumn{4}{|c|}{ a TML } & \multicolumn{4}{|c|}{ a TMSB } \\
\hline $\begin{array}{l}\text { Peak Position } \\
\text { In Extracts } \\
\left(\mathrm{cm}^{-1}\right)\end{array}$ & $\begin{array}{l}\text { Peak Position In } \\
\text { AgNPs At } 25^{\circ} \mathrm{C} \\
\left(\mathrm{cm}^{-1}\right)\end{array}$ & $\begin{array}{l}\text { Shift In } \\
\text { Position } \\
\left(\mathrm{cm}^{-1}\right)\end{array}$ & $\begin{array}{l}\text { Type Of } \\
\text { Chemical } \\
\text { Bond }\end{array}$ & $\begin{array}{l}\text { Peak } \\
\text { Position } \\
\text { In } \\
\text { Extracts } \\
\left(\mathrm{cm}^{-1}\right)\end{array}$ & $\begin{array}{l}\text { Peak Position In } \\
\text { AgNPs at } 70^{\circ} \mathrm{C} \\
\left(\mathrm{cm}^{-1}\right)\end{array}$ & $\begin{array}{l}\text { Shift In } \\
\text { Position } \\
\left(\mathrm{cm}^{-1}\right)\end{array}$ & $\begin{array}{l}\text { Type Of } \\
\text { Chemical } \\
\text { Bond }\end{array}$ \\
\hline 1338.32 & 1384.39 & +46.07 & $\begin{array}{l}\mathrm{C}-\mathrm{H} \text { methyl } \\
\text { rock alkanes }\end{array}$ & 1048.80 & --------- & ------.-- & C-O Stretch \\
\hline 1640.29 & 1638.56 & -1.73 & $\begin{array}{l}-\mathrm{C}=\mathrm{C}-\text { stretch } \\
\text { alkenes }\end{array}$ & 1131.16 & --------- & --------- & \\
\hline 1876.99 & 1884.90 & +7.91 & $\begin{array}{l}\mathrm{C}=\mathrm{O} \\
\text { Anhydrides }\end{array}$ & 1384.03 & 1384.96 & +0.93 & $\begin{array}{l}\text { C-H methyl } \\
\text { rock alkanes }\end{array}$ \\
\hline 2946.61 & 2830.64 & -115.97 & $\begin{array}{l}\mathrm{H}-\mathrm{C}=\mathrm{O}: \mathrm{C}-\mathrm{H} \\
\text { stretch } \\
\text { aldehydes }\end{array}$ & 1639.21 & 1638.68 & -0.53 & $\begin{array}{l}-\mathrm{C}=\mathrm{C}- \\
\text { stretch } \\
\text { alkenes }\end{array}$ \\
\hline 3530.47 & 3417.07 & -112.48 & $\begin{array}{l}\text { OH Alcohol, } \\
\text { phenols }\end{array}$ & 2016.03 & 2034.58 & +18.55 & $\begin{array}{l}-\mathrm{C} \equiv \mathrm{C}- \\
\text { stretch } \\
\text { alkynes }\end{array}$ \\
\hline 3545.10 & 3417.99 & -127.11 & & 2930.41 & 2789.28 & -141.13 & $\begin{array}{l}\mathrm{H}-\mathrm{C}=\mathrm{O}: \mathrm{C}-\mathrm{H} \\
\text { stretch } \\
\text { aldehydes }\end{array}$ \\
\hline 3647.29 & $37 \mid 2.96$ & +65.67 & & $\begin{array}{l}3530.72 \\
3544.94 \\
3717.06\end{array}$ & $\begin{array}{l}3530.35 \\
3544.99 \\
3731.61\end{array}$ & $\begin{array}{l}+0.37 \\
+0.05 \\
+14.55\end{array}$ & $\begin{array}{l}\text { OH Alcohol, } \\
\text { phenols }\end{array}$ \\
\hline
\end{tabular}

Note: Shift values were calculated by subtracting the peak position in TM-AgNPs from the peak position in TM-extracts.

Abbreviations: FTIR, Fourier-transform infrared; AgNPs, silver nanoparticles; TM, Terminalia mantaly; aTML, aqueous TM leaf extracts; a TMSB, aqueous TM stem bark.

tetrahedral and hexagonal shapes at $70^{\circ} \mathrm{C}$. Similar shapes as those of ${ }_{\mathrm{a}} \mathrm{TML}-\mathrm{AgNPs}$ were observed in AgNPs synthesized by the ${ }_{\mathrm{a}}$ TMSB extract. These anisotropic shapes were likely due to the reducing and capping phytochemicals which not only provided thermodynamic stability but also defined the NP bio-activities. ${ }^{34}$ The crystalline nature of the biogenic AgNPs was confirmed by their SAED patterns highlighted in Figure 4B. The Bragg reflection planes on the face-centered cubic ( $\mathrm{fcc}$ ) patterns of TMAgNPs, i.e. (111), (200), (220), (311), and (331) matched those in the database of the Joint Committee on Powder Diffraction Standards (JCPDS no. 00-004-0784, USA) $)^{51,52}$ and confirmed that the synthesized AgNPs are composed of pure crystalline silver. These findings are further supported by similar fcc patterns reported for the AgNPs synthesized from Cannabis sativa. ${ }^{51,53}$

Further characterization of the elemental composition of the TM-AgNPs by EDX confirmed the presence of a signal characteristic of elemental silver. The Energy
Dispersive Absorption photographs of the selected TMAgNPs in Figure 5 displays the $\mathrm{Ag}^{+}$peaks at $3 \mathrm{keV}$. Metallic AgNPs typically show a strong signal peak at this position due to their SPR. ${ }^{54}$ Peaks of other elements such as $\mathrm{Cu}$ and $\mathrm{C}$ were also detected, where $\mathrm{C}$ corresponds to the organic matrix and lacey carbon on the TEM grid, $\mathrm{Cu}$ is observed since the grid is made up of $\mathrm{Cu}$, and the $\mathrm{S}$, $\mathrm{Si}, \mathrm{Cl}$ and $\mathrm{N}$ peaks correspond to the molecules capping the TM-AgNPs.

\section{Antibacterial Activity Of TM Extracts And AgNPs}

The antibacterial effects of TM extracts and AgNPs were evaluated against eight bacterial strains, of which two were Gram positive (S. pneumoniae and S. aureus) and the other six were Gram negative. The bacterial cultures were treated with a single dose of $500 \mu \mathrm{g} / \mathrm{mL}$ of TM extracts and $12.5 \mu \mathrm{g} / \mathrm{mL}$ of TM-AgNPs. This was done as a quick and easy test of the antimicrobial 

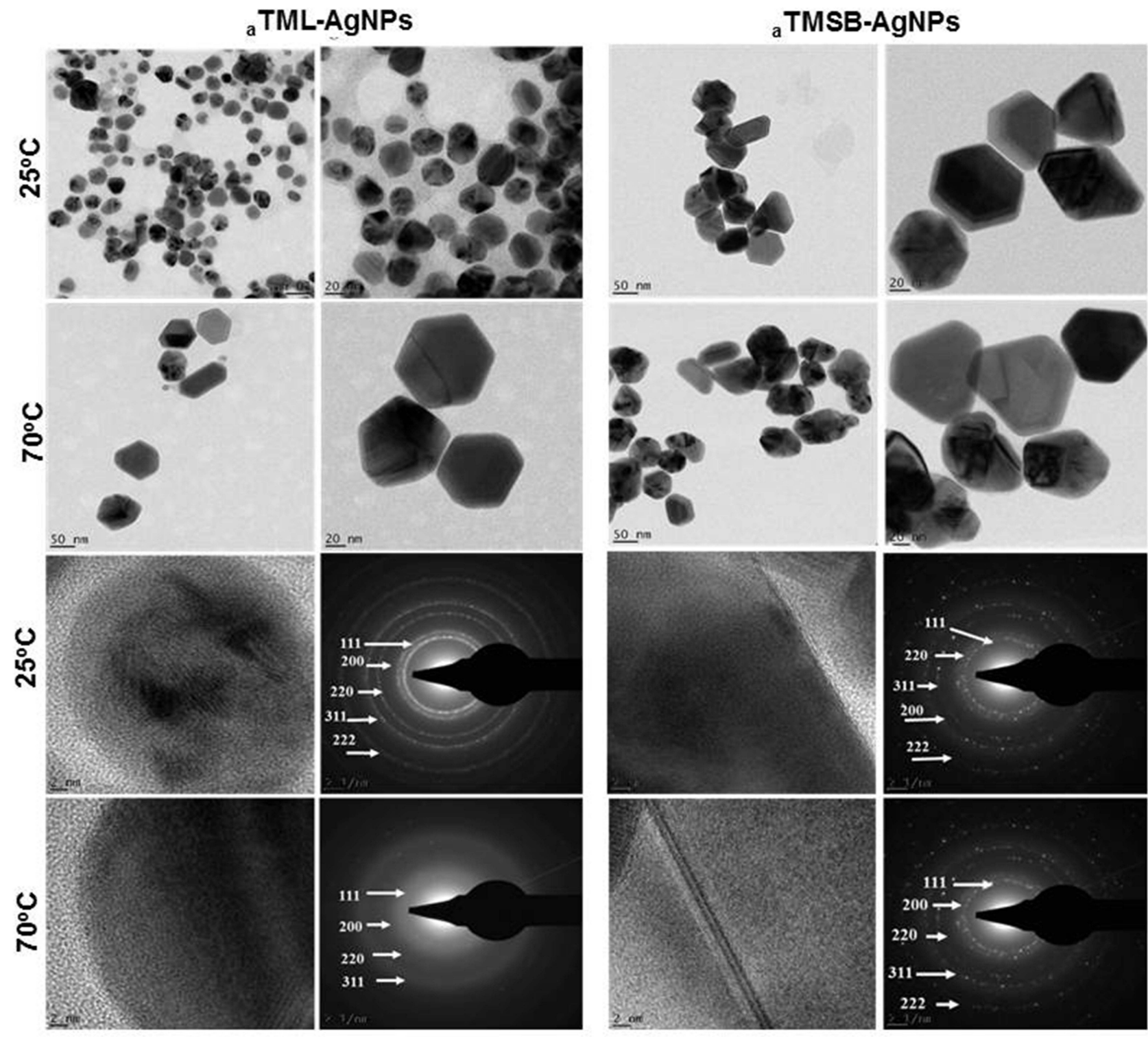

Figure 4 HRTEM micrographs and SAED patterns of selected TM-AgNPs.

Notes: The size, shapeand SAED patterns of ${ }_{\mathrm{a}} \mathrm{TML}-25^{\circ} \mathrm{C}$ and $\mathrm{m}_{\mathrm{m}} \mathrm{TML}-70^{\circ} \mathrm{CAgNPs}$ were analyzed by HRTEM. Scale bar from 20 to $50 \mathrm{~nm}$.

Abbreviations: AgNPs, silver nanoparticles; TM, Terminalia mantaly; aTML, aqueous TM leaf extract; aTMSB, aqueous TM stem bark; HRTEM, high resolution transmission election microscope; SAED, selected area electron diffraction.

activity of the TM extracts and TM-AgNPs. Figure 6 and Table 4 show that four of the treatments (aTMLAgNPs- $25^{\circ} \mathrm{C} \quad\left({ }_{\mathrm{a}}^{\mathrm{TML}}-\mathrm{AgNPs}\right.$ synthesised at $\left.25^{\circ} \mathrm{C}\right)$, a TML-AgNPs $-70^{\circ} \mathrm{C} \quad\left({ }_{\mathrm{a}} \mathrm{TML}-\mathrm{AgNPs}\right.$ synthesised at $70^{\circ} \mathrm{C}$ ), a TMSB-AgNPs- $25^{\circ} \mathrm{C}$ ( $\mathrm{T}$ TMSB-AgNPs synthesised at $25^{\circ} \mathrm{C}$ ) and ${ }_{\mathrm{m}} \mathrm{TMSB}$ ) inhibited the growth in a significant number of the eight bacterial strains tested in this study. ${ }_{\mathrm{a}}^{\mathrm{TML}} \mathrm{AgNPs}-25^{\circ} \mathrm{C}$ and ${ }_{\mathrm{a}}^{\mathrm{TML}} \mathrm{AgNPs}-70^{\circ} \mathrm{C}$ inhibited the growth in all eight strains, while ${ }_{\mathrm{a}} \mathrm{TMSB}-$ AgNPs $-25^{\circ} \mathrm{C}$ and ${ }_{\mathrm{m}} \mathrm{TMSB}$ inhibited the growth in $80 \%$ and $50 \%$ of the strains, respectively. ${ }_{\mathrm{m}} \mathrm{TMSB}$ was the most active extract and inhibited growth in a significant number (four) of the strains. Generally, three of the strains (K. pneumoniae, $H$. influenzae and $S$. flexneri) were more susceptible to the effects of the treatments, while S. enterica enterica was more resistant (Table 4).

The lowest concentration of the treatments required to inhibit visible growth of the bacteria (i.e. the MIC) was determined after $24 \mathrm{hr}$ treatment with the TM extracts and AgNPs. The MIC values for the treatments are summarized in Table 5. The lowest MIC value $(3.12 \mu \mathrm{g} / \mathrm{mL})$ was obtained for aTMSBAgNPs $-25^{\circ} \mathrm{C}$ and aTML-AgNPs- $25^{\circ} \mathrm{C}$ against $H$. influenzae. 

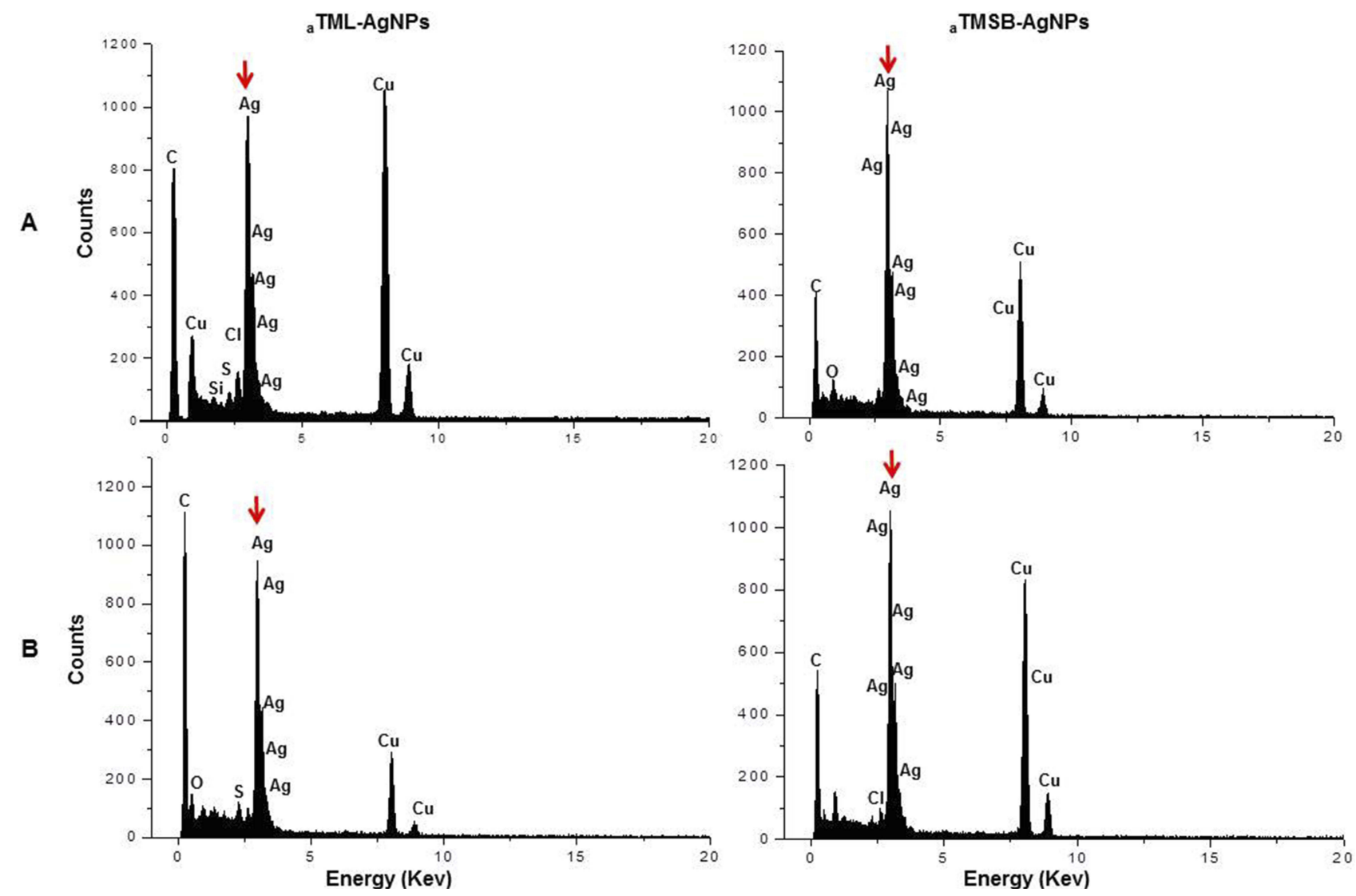

Figure 5 (A,B) EDX spectra of AgNPs synthesized from ${ }_{a} T M L$ and ${ }_{m} T M L$ AgNPs.

Notes: Silver nanocrystallites display an optical absorption band peak at approximately $3 \mathrm{keV}$ (red arrow), which is typical of the absorption of metallic silver nanocrystallites due to their SPR. Abbreviations: AgNPs, silver nanoparticles; TM, Terminalia mantaly; aTML, aqueous TM leaf extract; aTMSB, aqueous TM stem bark; EDX, Energy Dispersive X-ray.

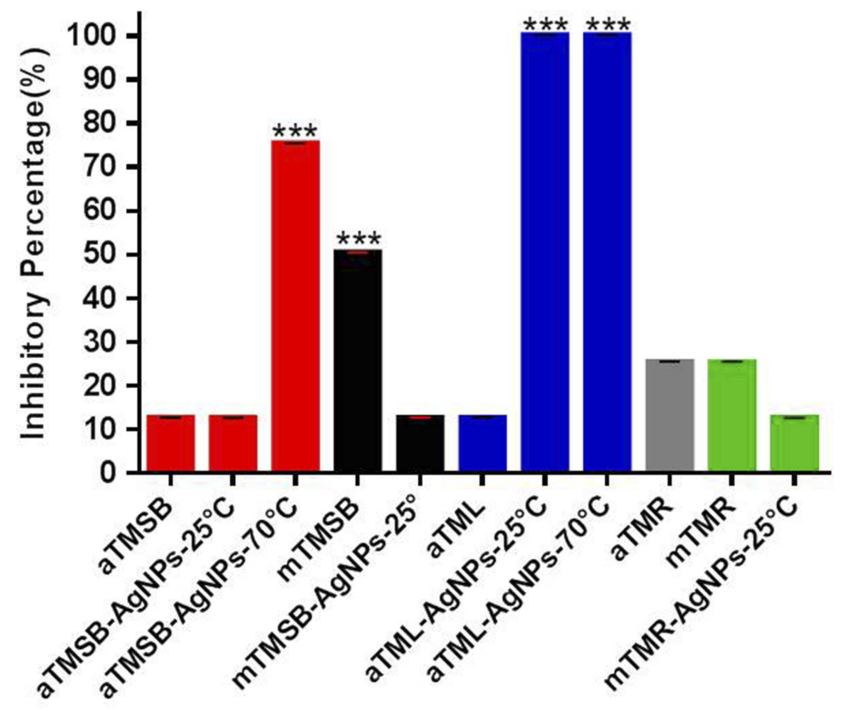

Figure 6 Screening of the antibacterial effects of TM extracts and AgNPs against a panel of bacterial strains.

Notes: Eight bacterial strains were treated with TM extracts and AgNPs for 24 hrs. Inhibitory effects of TM samples are expressed based on the number of strains that showed growth inhibition. ***P $<0.001$.

Abbreviations: AgNPs, silver nanoparticles; TM, Terminalia mantaly; a, represents aqueous extracts; ${ }_{m}$, represents methanolic extracts; TML, TM leaf extracts; TMR, TM root extracts; TMSB, TM stem bark extracts.
aTML-AgNPs $-25^{\circ} \mathrm{C}$ and aTMSB-AgNPs- $70^{\circ} \mathrm{C}$ appears to have more significant antimicrobial activity than the other TM-AgNPs. This is based on the findings that these two TMAgNPs have the lowest MIC values against the largest number of bacterial strains. MIC values for aTML-AgNPs- $25^{\circ} \mathrm{C}$ varied between 6.24 and $12.50 \mu \mathrm{g} / \mathrm{mL}$ in six of the eight strains, while the MIC values for aTMSB-AgNPs- $70^{\circ} \mathrm{C}$ varied between 3.12 and $6.24 \mu \mathrm{g} / \mathrm{mL}$ in five of the eight strains.

The absence of antibacterial activity observed in some of the AgNPs may be due to various factors, either the phytochemicals responsible for capping the NPs had adsorbed to the NPs through its active site, ${ }^{55}$ or the phytochemicals simply have no antibacterial activity as demonstrated by the crude extracts. Size of the NPs also plays a role in NP activity. NPs with smaller sizes are usually more efficient as they can easily pass through cellular barriers and disrupt the physiological functions of the bacteria once internalized. ${ }^{11}$ As such, the efficacy of ${ }_{a}^{T M L}$-AgNPs could be attributed to their smaller diameter. Their small size could allow for efficient binding and uptake by bacteria 
Table 4 Comparison Of The Bacterial Susceptibility To TM Extracts And AgNPs

\begin{tabular}{|c|c|c|c|c|c|c|c|c|}
\hline \multirow[t]{2}{*}{ Treatment } & \multicolumn{8}{|c|}{ Bacterial Strains } \\
\hline & S. enterica ${ }^{a}$ & S. pneumoniae & S. aureus & K. pneumoniae & $\begin{array}{l}\text { S. enterica } \\
\text { enterica }\end{array}$ & S. enterica ${ }^{b}$ & S. flexneri & H. influenzae \\
\hline aTMSB & - & - & - & - & - & - & - & $\checkmark$ \\
\hline${ }_{\mathrm{a}}$ TMSB-AgNPs- $25^{\circ} \mathrm{C}$ & - & - & - & $\checkmark$ & - & - & $\checkmark$ & $\checkmark$ \\
\hline${ }_{\mathrm{a}}$ TMSB-AgNPs- $70^{\circ} \mathrm{C}$ & - & $\checkmark$ & $\checkmark$ & $\checkmark$ & $\checkmark$ & $\checkmark$ & $\checkmark$ & - \\
\hline $\mathrm{m}$ TMSB & - & $\checkmark$ & - & - & $\checkmark$ & - & $\checkmark$ & $\checkmark$ \\
\hline${ }_{m}$ TMSB-AgNPs $-25^{\circ} \mathrm{C}$ & - & - & - & - & - & - & - & $\checkmark$ \\
\hline${ }_{\mathrm{a}} \mathrm{TML}$ & - & $\checkmark$ & - & - & - & - & - & - \\
\hline a TML-AgNPs- $25^{\circ} \mathrm{C}$ & $\checkmark$ & $\checkmark$ & $\checkmark$ & $\checkmark$ & $\checkmark$ & $\checkmark$ & $\checkmark$ & $\checkmark$ \\
\hline${ }_{\mathrm{a}}^{\mathrm{TM}} \mathrm{ML}-\mathrm{AgNP}-70^{\circ} \mathrm{C}$ & $\checkmark$ & $\checkmark$ & $\checkmark$ & $\checkmark$ & $\checkmark$ & $\checkmark$ & $\checkmark$ & $\checkmark$ \\
\hline a TMR & - & $\checkmark$ & - & - & - & - & - & $\checkmark$ \\
\hline $\mathrm{m} T \mathrm{TR}$ & - & $\checkmark$ & - & - & - & - & - & $\checkmark$ \\
\hline${ }_{m}$ TMR-AgNPs $-25^{\circ} \mathrm{C}$ & - & $\checkmark$ & - & - & - & - & - & - \\
\hline
\end{tabular}

Notes: Eight bacterial strains were treated with TM extracts and AgNPs for 24 hrs. Inhibitory effects of TM samples were visually assessed to identify the strains that were susceptibility to TM extracts and AgNPs. The ${ }_{\mathrm{a}} \mathrm{TM}-\mathrm{AgNPs}$ were the most active and inhibited growth of all bacterial strains, compared to the crude extracts and other AgNPs. S. enterica ${ }^{a}$ (Salmonella enterica subsp. enterica A36 (Serovar Typhimurium) vs S. enterica ${ }^{b}$ (Salmonella enterica subsp. enterica 2004 Pennsylvania Tomato Outbreak, Serovar Anatum, Isolate 4).

Abbreviations: AgNPs, Silver nanoparticles; TM, Terminalia mantaly; a, represents aqueous extracts; ${ }_{m}$, represents methanolic extracts; TML, TM leaf extracts; TMR, TM root extracts; TMSB, TM stem bark extracts; S. pneumoniae, Streptococcus pneumoniae; S. enterica enterica, Salmonella enterica enterica; $H$. influenzae, Haemphilus influenzae, S. flexineri, Shigella flexineri; K. pneumoniae, Kbesiella pneumoniae; S. aureus, Staphylococcus aureus, S. enterica- Salmonella enterica; -, no bacterial activity; $\checkmark$, bacterial activity.

Table 5 MIC For Crude TM Extracts And Its Derivate AgNPs On Selected Bacterial Strains

\begin{tabular}{|c|c|c|c|c|c|c|c|c|}
\hline \multirow[t]{2}{*}{ Treatment } & \multicolumn{8}{|c|}{ MIC $(\mu \mathrm{g} / \mathrm{mL})$} \\
\hline & S. enterica ${ }^{a}$ & S. pneumoniae & S. aureus & K. pneumoniae & $\begin{array}{l}\text { S. enterica } \\
\text { enterica }\end{array}$ & S. enterica ${ }^{b}$ & S. flexneri & H. influenzae \\
\hline aTMSB & $>500$ & $>500$ & $>500$ & $>500$ & $>500$ & $>500$ & $>500$ & 125 \\
\hline aTMSB-AgNPs- $25{ }^{\circ} \mathrm{C}$ & $>12.50$ & $>12.50$ & $>12.50$ & 6.24 & $>12.50$ & 6.24 & $>12.50$ & 3.12 \\
\hline aTMSB-AgNPs-70 ${ }^{\circ} \mathrm{C}$ & $>12.50$ & 6.24 & 12.50 & 6.24 & 12.50 & 12.50 & $>12.50$ & $>12.50$ \\
\hline $\mathrm{m}$ TMSB & $>500$ & $>500$ & $>500$ & $>500$ & $>500$ & $>500$ & 125 & $>500$ \\
\hline${ }_{m}$ TMSB-AgNPs- $25{ }^{\circ} \mathrm{C}$ & $>12.50$ & $>12.50$ & $>12.50$ & $>12.50$ & $>12.50$ & $>12.50$ & $>12.50$ & 6.24 \\
\hline $\mathrm{a} T M L$ & $>500$ & $>500$ & $>500$ & $>500$ & $>500$ & $>500$ & $>500$ & $>500$ \\
\hline a TML-AgNPs- $25{ }^{\circ} \mathrm{C}$ & 6.24 & 6.24 & 6.24 & 6.24 & $>12.50$ & 6.24 & $>12.50$ & 3.12 \\
\hline${ }_{a} T M L-A g N P-70^{\circ} \mathrm{C}$ & $>12.50$ & 6.24 & 12.50 & 6.24 & $>12.50$ & 6.24 & $>12.50$ & $>12.50$ \\
\hline $\mathrm{a} T M R$ & $>500$ & $>500$ & $>500$ & $>500$ & $>500$ & $>500$ & $>500$ & 500 \\
\hline${ }_{m}^{T M R}$ & $>500$ & $>500$ & $>500$ & $>500$ & 125 & $>500$ & $>500$ & $>500$ \\
\hline${ }_{m}$ TMR-AgNPs $25^{\circ} \mathrm{C}$ & $>12.50$ & $>12.50$ & $>12.50$ & $>12.50$ & $>12.50$ & $>12.50$ & $>12.50$ & $>12.50$ \\
\hline Ampicillin & 32 & 4 & 8 & 16 & 32 & 16 & 32 & 16 \\
\hline
\end{tabular}

Notes: S. enterica (Salmonella enterica subsp. enterica A36 (Serovar Typhimurium) vs S. enterica ${ }^{b}$ (Salmonella enterica subsp. enterica 2004 Pennsylvania Tomato Outbreak, Serovar Anatum, Isolate 4).

Abbreviations: AgNPs, Silver nanoparticles; TM, Terminalia mantaly; , represents aqueous extracts; $m$, represents methanolic extracts; TML, TM leaf extracts; TMR, TM root extracts; TMSB, TM stem bark extracts; S.pneumoniae, Streptococcus pneumoniae; S. enterica enterica, Salmonella enterica enterica; H.influenzae, Haemphilus influenzae, S. flexineri, Shigella flexineri; K. pneumoniae, Kbesiella pneumoniae; S. aureus, Staphylococcus aureus; S. enterica, Salmonella enterica.

resulting in their death. ${ }^{56}$ Furthermore, the active phytochemicals at specific temperatures might be responsible for the biological activities of the AgNPs. ${ }^{19}$ Only S. enterica enterica, $S$. flexineri and $H$. influenzae were susceptible to the ${ }_{\mathrm{m}} \mathrm{TMR},{ }_{\mathrm{a}} \mathrm{TMSB}$ and ${ }_{\mathrm{m}} \mathrm{TMSB}$ extracts. The MIC for these extracts was $125 \mu \mathrm{g} / \mathrm{mL}$. The other strains were not susceptible to the effect of the TM extracts at concentrations up to $500 \mu \mathrm{g} / \mathrm{mL}$, the MIC values for these extracts could not be established in this study. Previous studies have demonstrated the antifungal activity of the aqueous and ethanolic TML and TMSB extracts against Candida species (C. albicans, C. albicans, C. glabrata C, parapsilosis) and Cryptococcus neoformans with MIC values ranging from 0.04 to $0.16 \mathrm{mg} / \mathrm{mL} .{ }^{32}$ Although the extracts did not show 

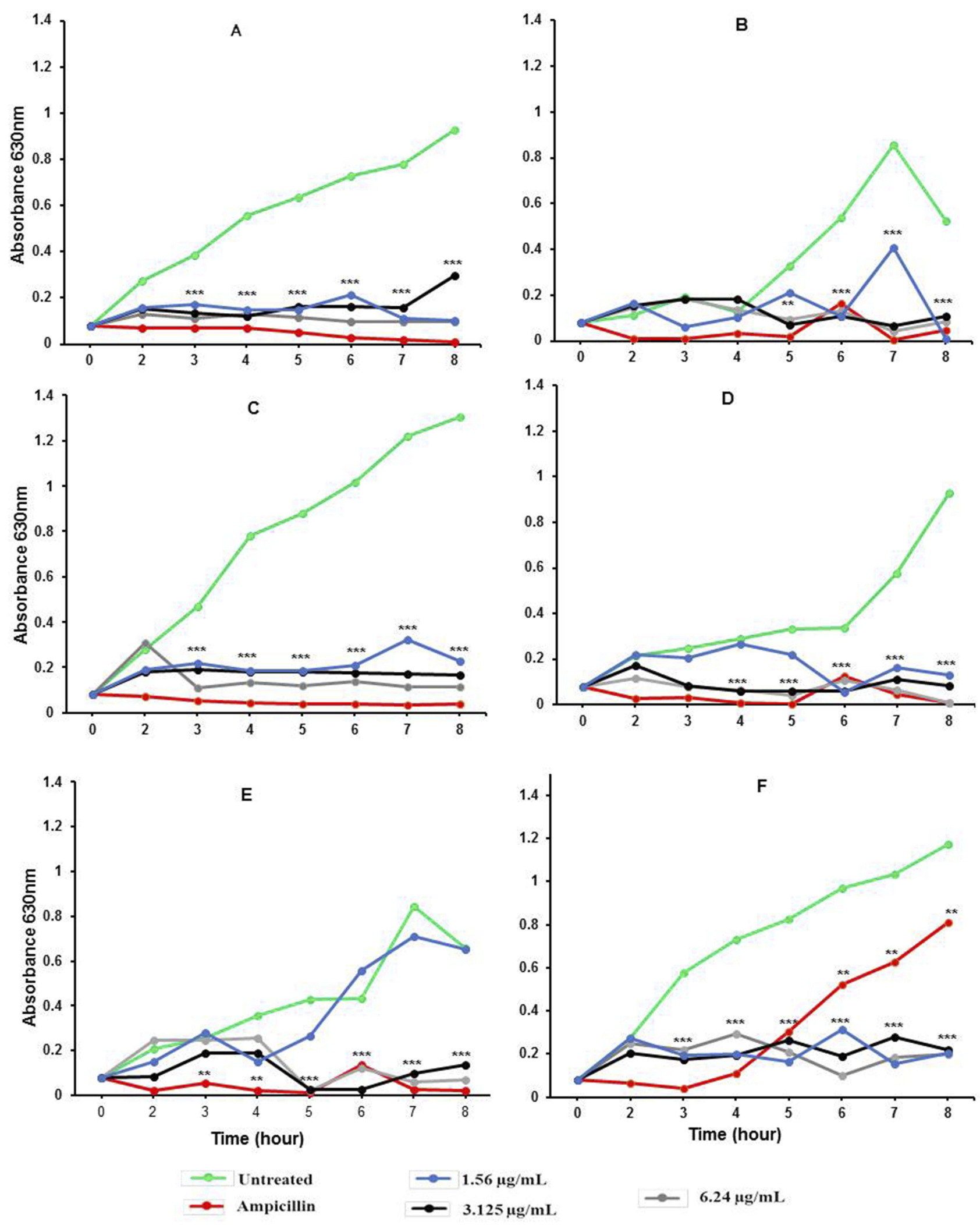

Figure 7 Growth inhibitory activities of ${ }_{\mathrm{a}} \mathrm{TML}-\mathrm{AgNPs}-25^{\circ} \mathrm{C}$ against selected bacterial strains.

Notes: Growth curves of (A) S. pneumoniae, (B) S. enterica enterica, (C) H. influenza, (D) S. flexneri, (E) K. pneumoniae, and (F) S. enterica ${ }^{a}$ (Salmonella enterica subsp. enterica A36 Serovar Typhimurium) after $24 \mathrm{hr}$ treatment. $* * \mathrm{P}<0.01$, $* * * \mathrm{P}<0.001$.

Abbreviations: AgNPs, Silver nanoparticles; TM, Terminalia mantaly; ${ }_{a}$ TML-AgNPs, AgNPs synthesized from aqueous leaf extracts from TM; S. pneumoniae, Streptococcus pneumoniae; S. enterica enterica, Salmonella enterica enterica; H. influenzae, Haemphilus influenzae, S. flexineri, Shigella flexineri; K. Pneumoniae, Klebsiella pneumoniae; S. aureus, Staphylococcus aureus; S. enterica, Salmonela enterica. 

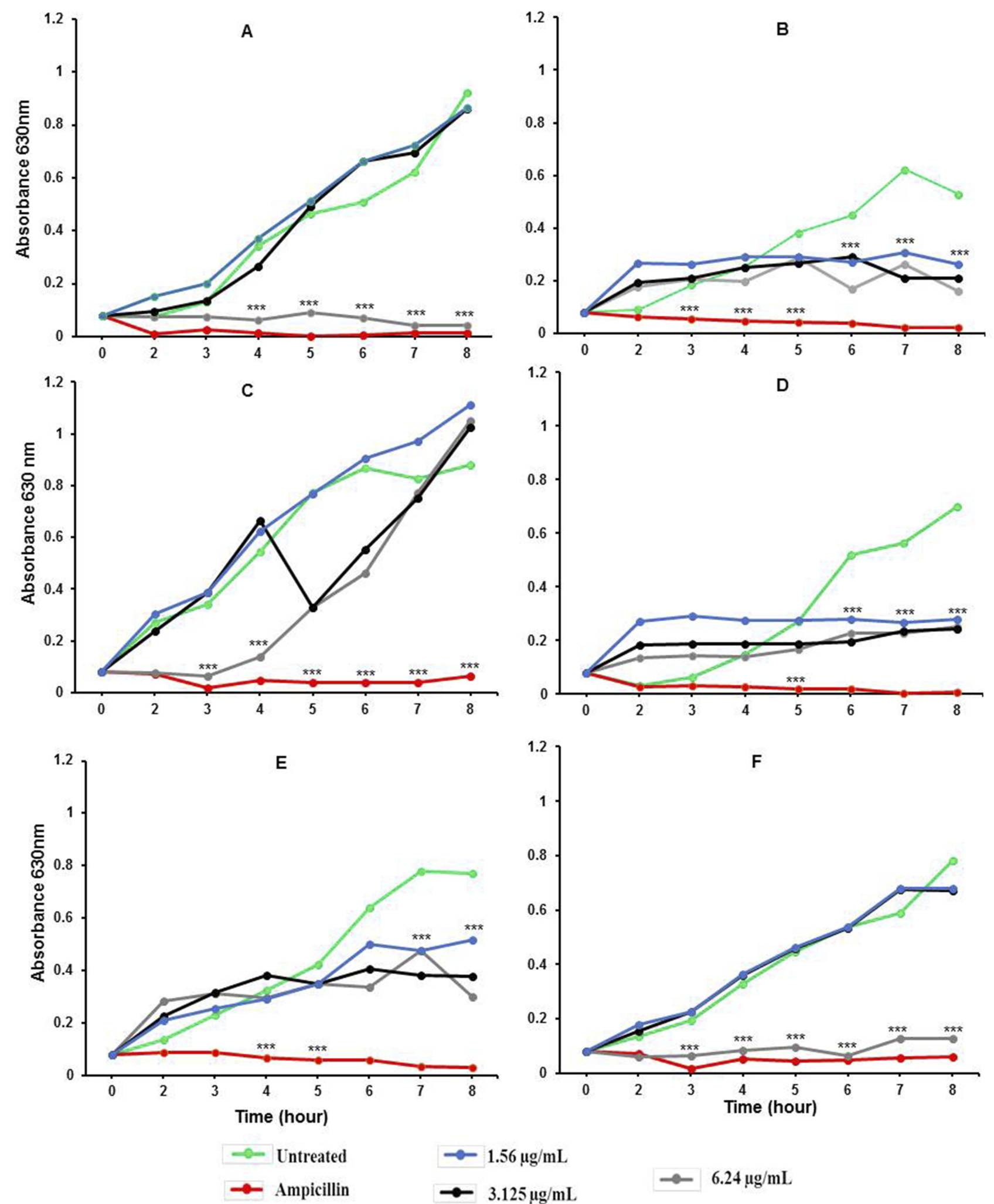

$1.56 \mu \mathrm{g} / \mathrm{mL}$

$3.125 \mu \mathrm{g} / \mathrm{mL}$

$\rightarrow \quad 6.24 \mu \mathrm{g} / \mathrm{mL}$

Figure 8 Growth inhibitory activities of ${ }_{\mathrm{a}} \mathrm{TMSB}-\mathrm{AgNPs}-70^{\circ} \mathrm{C}$ against selected bacterial strains.

Notes: Growth curves of (A) S. pneumoniae, (B) S. enterica enterica, (C) H. influenzae, (D) S. flexneri, (E) K. pneumoniae, and (F) S. aureus after $24 \mathrm{hr}$ treatment. ****P $<0.00 \mathrm{I}$.

Abbreviations: AgNPs, Silver nanoparticles; TM, Terminalia mantaly; ${ }_{a}$ TMSB-AgNPs, AgNPs synthesized from aqueous Stem Bark extracts from TM; S. pneumoniae, Streptococcus pneumoniae; S. enterica enterica, Salmonella enterica enterica; H. influenzae, Haemphilus influenzae, S. flexineri, Shigella flexineri; K. pneumoniae, Klebsiella pneumoniae;

S. aureus, Staphylococcus aureus; S. enterica, Salmonella enterica. 
the same response in bacteria, their respective AgNPs possess enhanced anti-bacterial activities against both Gramnegative and Gram-positive strains.

\section{Growth Inhibitory Kinetics Of TM-AgNPs}

Based on the results for the antibacterial screening (Figure 6), a TML-AgNPs synthesised at $25^{\circ} \mathrm{C}\left({ }_{\mathrm{a}} \mathrm{TML}-\mathrm{AgNPs}-25^{\circ} \mathrm{C}\right)$ and a TMSB-AgNPs synthesised at $70^{\circ} \mathrm{C}$ ( $\mathrm{a}$ TMSB-AgNPs-70 ${ }^{\circ} \mathrm{C}$ ) showed the highest antibacterial activities. The bacterial growth kinetics of several bacterial strains was evaluated in response to treatment with these two TM-AgNPs. Figures 7 and 8 show the effects of ${ }_{\mathrm{a}}$ TML-AgNPs $-25^{\circ} \mathrm{C}$ and ${ }_{\mathrm{a}} \mathrm{TMSB}-$ AgNPs- $70^{\circ} \mathrm{C}$, respectively.

Changes in optical density (OD) were used to assess bacterial growth. This provides an easy and efficient way to quantify bacterial growth over time. A decrease in the absorbance indicates the inhibition of bacterial growth, an effect that can be attributed to the death of cells that is blocked in the stationary phase. ${ }^{57}$ As shown in Figures 7 and 8, both TM-AgNPs caused a time- and dose-dependent growth inhibition in the selected strains. Of the two TM-AgNPs, a TMLAgNPs $-25^{\circ} \mathrm{C}$ (Figure 7) was more effective and had the highest bactericidal effect against the microorganisms. a TML-AgNPs- $25^{\circ} \mathrm{C}$ suppressed the growth of all six bacterial strains tested. Interestingly, the growth curve for $S$. enterica shows that the inhibitory effects of ampicillin diminish after 4 hrs, while inhibitory effects of ${ }_{\mathrm{a}} \mathrm{TML}-\mathrm{AgNPs}-25^{\circ} \mathrm{C}$ are maintained for the duration of the experiment at all the concentrations tested. The bacteriostatic effects of ${ }_{\mathrm{a}}$ TMSBAgNPs- $70{ }^{\circ} \mathrm{C}$ were observed against all strains except for $H$. influenzae and $S$. aureus (Figure 8). The growth curves of $S$. enterica enterica and $S$. flexneri show that ${ }_{\mathrm{a}}$ TMSB-AgNPs$70^{\circ} \mathrm{C}$ is able to effectively inhibit the growth of these two organisms from 2 to $8 \mathrm{hrs}$ at all the concentrations tested. Only higher concentrations $(6.24 \mu \mathrm{g} / \mathrm{mL})$ of ${ }_{\mathrm{a}}$ TMSB-AgNPs$70^{\circ} \mathrm{C}$ were effective on $S$. pneumoniae and $S$. aureus at all time points. In general, the Gram-negative bacteria were more susceptible to the effects of the TM-AgNPs than Gram-positive bacteria (S. pneumoniae and S. aureus). This might be due to the structural differences between the two bacterial types, a key component being the cell membrane of the Gram-positive bacteria, where the thick peptidoglycan layer acts as a barrier against penetration of foreign materials. $^{20,58}$ The thick and negatively charged peptidoglycan layer in Gram-positive bacteria has been shown to entrap $\mathrm{Ag}^{+}$ions onto the cell wall and block their activity. ${ }^{59}$ The exact mechanism of antibacterial action of AgNPs is not yet known. ${ }^{60,61}$ Nonetheless, several studies have demonstrated that bactericidal effects of the AgNPs are strongly influenced by their size, shape, concentration, and colloidal state. ${ }^{62,63}$

\section{Conclusion}

This study reports on a plant-mediated approach to synthesize AgNPs using TM leaf, stem bark and root extracts as both reducing and capping agents. The biogenic TML and TMSB AgNPs remained stable for more than 2 weeks, while those within a diameter ranging from 11 to $60 \mathrm{~nm}$ exhibited remarkable antibacterial activity against the tested pathogenic microorganisms. The ${ }_{\mathrm{a}} \mathrm{TM}$ AgNPs demonstrated the highest bactericidal effect, and compared to the crude extracts, their activity was $\geq 20$-fold higher. The rise in the number of antimicrobial-resistant bacterial strains underpins the need for alternative antimicrobial agents. The biogenic AgNPs described in this study can potentially be used as an alternative to conventional antimicrobial agents. Further studies are underway to study the anti-microbial mechanism of TMAgNPs and identify the phytochemicals involved in the synthesis of the NPs.

\section{Acknowledgment}

We thank the Organization for Women in Science for the Developing World (OWSD) for sponsoring Ms Michele Majoumouo's PhD studies (2017-2019). We also thank the DST/Mintek NIC and Chemical Industries Education \& Training Authority (CHIETA) for financial assistance. This work also received materials and equipment support from Yaoundé-Bielefeld Bilateral Graduate School for Natural Products with Anti-parasite and Antibacterial Activity (YaBiNaPA) and the Seeding Labs' Instrumental Access.

\section{Disclosure}

The authors report no conflicts of interest in this work.

\section{References}

1. Laxminarayan R, Matsoso P, Pant S, et al. Access to effective antimicrobials: a worldwide challenge. Lancet. 2016;387:168-175. doi:10.1016/S0140-6736(15)00474-2

2. CDC: Centers for Disease Control and Prevention. Antibiotic resistance threats in the United States. Annu Rep. 2013;508.

3. De la Fuente-Núñez C, Re $\square$ uveille F, Fernández L, Hancock RE. Bacterial biofilm development as a multicellular adaptation: antibiotic resistance and new therapeutic strategies. Curr Opin Microbiol. 2013;16:580-589. doi:10.1016/j.mib.2013.06.013

4. Smith WD, Bardin E, Cameron L, Edmondson CL, Farrant KV, Martin I. Current and future therapies for Pseudomonas aeruginosa infection in patients with cystic fibrosis. FEMS Microbiol Lett. 2017;364.

5. Mohammed EA, Al-Qahtani A, Al-Mutairi A, Al-Shamri B, Aabed K. Antibacterial and cytotoxic potential of biosynthesized silver nanoparticles by some plant extracts. Nanomaterials. 2018;8(6):E382. 
6. El-Chaghaby GA, Ahmad AF. Biosynthesis of silver nanoparticles using Pistacial entiscus leaves extract and investigation of their antimicrobial effect. Orient J Chem. 2011;27:929-936.

7. Veerasamy R, Xin TZ, Gunasagaran S, et al. Biosynthesis of silver nanoparticles using Mangosteen leaf extract and evaluation of their antimicrobial activities. J Saudi Chem Soc. 2011;15:113-120. doi:10.1016/j.jscs.2010.06.004

8. Ahmed S, Ikram S. Silver nanoparticles: one pot green synthesis using Terminalia arjuna extract for Biological application. Nanomed Nanotechnol. 2015;6:7.

9. Wang D, Josua M, Yeon-Ju K, et al. Coalescence of functional gold and monodisperse silver nanoparticles mediated by black Panax ginseng Meyer root extract. Int J Nanomedicine. 2016;14.

10. Yuan CG, Huo C, Gui B, Cao WP. Green synthesis of gold nanoparticles using Citrus maxima peel extract and their catalytic/antibacterial activities. IET Nanobiotechnol. 2017;11:523-530. doi:10.1049/ietnbt.2016.0183

11. Aljabali AAA, Yazan Akkam IDY, Al Zoubi IDMS, et al. Synthesis of gold nanoparticles using leaf extract of Ziziphus zizyphus and their antimicrobial activity. Nanomaterials. 2018;8:174. doi:10.3390/ nano8030174

12. Dhillon GS, Brar SK, Kaur S, Verma M. Green approach for nanoparticle biosynthesis by fungi: current trends and applications. Crit Rev Biotechnol. 2012;32:49-73. doi:10.3109/07388551.2010.550568

13. Mittal AK, Chisti Y, Banerjee UC. Synthesis of metallic nanoparticles using plant extracts. Biotechnol Adv. 2013;31:46-456. doi:10.1016/j.biotechadv.2013.01.003

14. Khatami M, Nejad MS, Pourseyedi SH. Biogenic synthesis of silver nanoparticles using mustard and its characterization. Int J Nanosci Nanotechnol. 2015;11(4):281-288.

15. Singh V, Shrivastava A, Wahi N. Biosynthesis of silver nanoparticles by plants crude extracts and their characterization using UV, XRD, TEM and EDX. Afr J Biotechnol. 2015;14(33):2554-2567. doi:10.5897/AJB2015.14692

16. Kharissova OV, Dias HV, Kharisov BI, Perez BO, Perez VMJ. The greener synthesis of nanoparticles. Trends Biotechn. 2013;31:240 doi:10.1016/j.tibtech.2013.01.003

17. Malarkodi C, Rajeshkumar S, Paulkumar K, Vanaja M, Gnanajobitha G, Annadurai G. Biosynthesis and antimicrobial activity of semiconductor nanoparticles against oral pathogens. Bioin Chem Appl. 2014;2014:1-10. doi:10.1155/2014/347167

18. Sekhar EC, Rao KSKV, Rao MS, Alisha SB. A simple biosynthesis of silver nanoparticles from Syzygium cumini stem bark aqueous extract and their spectrochemical and antimicrobial studies. $J$ Appl Pharm Sci. 2018;8(1):73-79.

19. El-Rafie MH, Hamed MAA. Antioxidant and anti-inflammatory activities of silver nanoparticles biosynthesized from aqueous leaves extracts of four Terminalia species. Adv Nat Sci Nanosci Nanotechnol. 2014;5:11.

20. Dakal TC, Kumar A, Majumdar RS, Yadav V. Mechanistics basics of antimicrobials action of silver nanoparticles. Front Microbiol. 2016;7:1831. doi:10.3389/fmicb.2016.01831

21. Wang D, Markus J, Wang C, et al. Green synthesis of gold and silver nanoparticles using aqueous extract of Cibotium barometz root. Artif Cells Nanomed Biotechnol. 2017;45:1548-1555.

22. Sondi I, Salopek-Sondi B. Silver nanoparticles as antimicrobial agent: a case study on Escherichia coli as a model for Gram-negative bacteria. $J$ Colloid Interf Sci. 2004;275:177-182. doi:10.1016/j.jcis.2004.02.012

23. Jain J, Arora S, Rajwade JM, Omray P, Khandelwal S, Paknikar KM. Silver nanoparticles in therapeutics: development of an antimicrobial gel formulation for topical use. Mol Pharm. 2009;6:1388-1401. doi:10.1021/mp900056g

24. Tippayawat P, Phromviyo N, Parichart B, Chompoosor A. Green synthesis of silver nanoparticle using Aloe vera plant extract prepared by a hydrothermal method and their synergistic antibacterial activity. Peer J. 2016;4:1-16.
25. Alshaye NA, Elobeid MM, Alkhalifah DHM, Mohammed AE. Characterization of biogenic silver nanoparticles by Salvadora persica leaves extract and Its application against some MDR pathogens E. coli and S. Aureus. Res J Microbiol. 2017;12:74-81.

26. Hwang ET, Lee JH, Chae YJ, et al. Analysis of the toxic mode of action of silver nanoparticles using stress-specific bioluminescent bacteria. Small. 2008;4(6):746-750. doi:10.1002/smll.200700954

27. Panacek A, Kvitek L, Prucek R, et al. Silver colloid nanoparticles synthesis characterization and their antibacterial activity. J Phs Chem B. 2006;110(33):16248-16253. doi:10.1021/jp063826h

28. Chwalibog A, Sawosz E, Hotowy A, et al. Visualization of interaction between inorganic nanoparticles and bacteria or fungi. Int $J$ Nanomed. 2010;5:1085-1094. doi:10.2147/IJN.S13532

29. Therese KL, Bagyalakshmi R, Madhavan HN, Deepa P. In vitro susceptibility testing by agar dilution method to determine the minimum inhibitory concentrations of amphotericin B, fluconazole and ketoconazole against ocular fungal isolates. Ind $\mathrm{J}$ Med Microbiol. 2006;24:273-279. doi:10.4103/0255-0857.29386

30. Kumar KM, Mandal BK, Kumar KS, Reddy PS. Biobased green method to synthesise palladium and iron nanoparticles using Terminalia chebula aqueous extract. Spectrochim Acta A $\mathrm{Mol}$ Biomol Spectrosc. 2013;102:128-133.

31. Ankamwar B. Biosynthesis of gold nanoparticles (green-gold) using leaf extract of Terminalia catappa. J Chem. 2010;7:1334-1339.

32. Ngouana KT, Mbouna JCD, Kuipou TRM, et al. Potent and synergistic extract combinations from Terminalia catappa, Terminalia mantaly and Monodora tenuifolia against pathogenic yeasts. Medicines. 2015;2:220-235. doi:10.3390/medicines2030220

33. Tchuenmogne TMA, Kammalac NT, Gohlke S, et al. Compounds from Terminalia mantaly L. stem bark exhibit potent inhibition against some pathogenic yeasts and enzymes of metabolic significance. Medicines. 2017;4:6. doi:10.3390/medicines4010006

34. Kumar KM, Sinha M, Mandal BK, Ghosh AR, Kumar KS, Reddy PS. Green synthesis of silver nanoparticles using Terminalia chebula extract at room temperature and their antimicrobial studies. Spectrochim Acta A. 2012;91:228-233. doi:10.1016/j.saa.2012.02.001

35. Elbagory AM, Cupido CN, Meyer M, Hussein AA. Large scale screening of southern african plant extracts for the green synthesis of gold nanoparticles using microtitre-plate method. Molecules. 2016;20.

36. CLSI. Methods for Dilution Antimicrobial Susceptibility Tests for Bacteria that Grow Aerobically; Approved Standard-Ninth Edition Document M07A9. Clinical Laboratory Standard Institute; 2012.

37. Cao L, Dai C, Li Z, et al. Antibacterial activity and mechanism of a scorpion venom peptide derivative in Vitro and in Vivo. PLoS One. 2012;7(7):11.

38. Moodley JS, Krishna SBN, Sershen KP, Govender P. Green synthesis of silver nanoparticles from Moringa oleifera leaf extracts and its antimicrobial potential. Adv Nat Sci Nanosci Nanotechnol. 2018;9.

39. Raza MA, Kanwal Z, Rauf A, Sabri AN, Riaz S, Naseem S. Size and shape-dependent antibacterial studies of silver nanoparticles synthesized by wet chemical routes. Nanomaterials. 2016;6:74. doi:10.3390/ nano6040074

40. Govindappa M, Farheen H, Chandrappa CP, Channabasava R, Rai RV, Raghavendra VB. Mycosynthesis of silver nanoparticles using extract of endophytic fungi, Penicillium species of Glycosmis mauritiana and its antioxidant, antimicrobial, anti-inflammatory and tyrokinase inhibitory activity. Adv Nat Sci Nanosci Nanotechnol. 2016;7:03501. doi:10.1088/2043-6262/7/3/035014

41. Kannan N, Shekhawat MS, Ravindran CP, Manokari M. Preparation of silver nanoparticles using leaf and fruit extracts of Morinda coreia Buck. Ham. -A green approach. J Sci Innov Res. 2014;3(3):315-318.

42. Sharma R, Dhillon A, Kumar D. Mentha-Stabilized silver nanoparticles for high performance colorimetric detection of Al (III) in aqueous systems. Sci Rep. 2018;8:5189. doi:10.1038/s41598-018-23469-1 
43. Hiemenz PC, Rajagopalan R. Principles Of Colloid And Surface Chemistry. 3rd ed. New York, NY, USA: Marcel Dekker;1997:650-664.

44. Clayton KN, Salameh JW, Wereley ST, Kinzer-Ursem T. Physical characterization of nanoparticle size and surface modification using particle scattering diffusometry. Biomicrofluidics. 2016;10:14. doi:10.1063/ 1.4962992

45. International Standard ISO13321. Methods for Determination of Particle Size Distribution Part 8: Photon Correlation Spectroscopy. ISO;1996.

46. Wu L, Zhang J, Watanabe W. Physical and chemical stability of drug nanoparticles. Adv Drug Deliv Rev. 2011;63:456-469. doi:10.1016/j. addr.2011.02.001

47. Singh P, Kim YJ, Zhang D, Yang DC. Biological synthesis of nanoparticles microorganisms. Trends Biotechnol. 2016;34:88-599. doi:10.1016/j.tibtech.2016.02.006

48. Elbagory AM, Meyer M, Cupido $\mathrm{CN}$, Hussein AA. Inhibition of bacteria associated with wound infection by biocompatible green synthesized gold nanoparticles from South African plant extracts. Nanomaterials. 2017;7:417. doi:10.3390/nano7120458

49. Fahmy NM, Al-Sayed E, Singab AN. Genus Terminalia: A phytochemical and biological review. Med Aromat Plants. 2015;4:5.

50. Patra JK, Baek KH. Novel green synthesis of gold nanoparticles using Citrullus lanatus rind and investigation of proteasome inhibitory activity, antibacterial, and antioxidant potential. Int $J$ Nanomedicine. 2015;10:7253-7264. doi:10.2147/IJN.S95483

51. Bagherzade G, Mohmmad MT, Namaei H. Green synthesis of silver nanoparticles using aqueous extract of saffron (Crocus sativus L.) wastages and its antibacterial activity against six bacteria. Asian Pac J Trop Biomed. 2017;7:227-233. doi:10.1016/j.apjtb.2016.12.014

52. Singh P, Pandit S, Garnæs J, et al. Green synthesis of gold and silver nanoparticles from Cannabis sativa (industrial hemp) and their capacity for biofilm inhibition. Int J Nanomedicine. 2018;13:3571-3591. doi:10.2147/IJN.S157958

53. Escárcega-González EC, Garza-Cervantes JA, Vázquez-Rodríguez A, et al. In vivo antimicrobial activity of silver nanoparticles produced via a green chemistry synthesis using Acacia rigidula as a reducing and capping agent their anticancer activities. Int $J$ Nanomedicine. 2018;13:2349-2363. doi:10.2147/IJN.S160605
54. Prakash P, Gnanaprakasam P, Emmanuel R, Arokiyaraj S, Saravanan M. Green synthesis of silver nanoparticles from leaf extract of Mimusops elengi, Linn for enhanced antibacterial activity against multi drug resistant clinical isolates. Colloid Surf B. 2013;108:255259. doi:10.1016/j.colsurfb.2013.03.017

55. Anandalakshmi K, Venugobal J, Ramasamy V. Characterization of silver nanoparticles by green synthesis method using Pedalium murex leaf extract and their antibacterial activity. Appl Nanosci. 2016;6:399-408. doi:10.1007/s13204-015-0449-z

56. Mmola M, Le Roes-Hill M, Durrell K, et al. Enhanced antimicrobial and anticancer activity of silver and gold nanoparticles synthesized using Sargassum incisifolium aqueous extracts. Mol. 2016;21:1633. doi: $10.3390 /$ molecules21121633

57. Chudasama B, Vala AK, Andhariya N, Mehta RV, Upadhyay RV. Highly bacterial resistant silver nanoparticles: synthesis and antibacterial activities. J Nanopart Res. 2010;12(5):1677-1685. doi:10.1007/ s11051-009-9845-1

58. Holowachuk SA, Farid MB, Buddington RK. A kinetic microplate method for quantifying the antibacterial properties of biological fluids. J Microbiol Methods. 2003;55:441-446.

59. Hajipour MJ, Fromm KM, Ashkarran AA, et al. Antibacterial properties of nanoparticles. Trends Biotechnol. 2012;30:499-511. doi:10.1016/j.tibtech.2012.06.004

60. Feng QL, Wu J, Chen GQ, Gui FZ, Kim TN, Kim JO. Mechanistic study of the antibacterial effect of silver nanoparticles on Escherichia Coli and Staphylococcus aureus. J Biomed Mater Res. 2000;52(4):662-668. doi:10.1002/1097-4636(20001215)52:4<662::aid-jbm10>3.0.co;2-3

61. Kim J, Kuk E, Yu KN, et al. Antimicrobial effects of silver nanoparticles. Nanomedicine. 2007;3:95-101. doi:10.1016/j.nano.2006.12.001

62. Jiang J, Oberdörster G, Biswas P. Characterization of size, surface charge, and agglomeration state of nanoparticle dispersions for toxicological studies. J Nanopart Res. 2009;11:77-89. doi:10.1007/ s11051-008-9446-4

63. Rai M, Kon K, Ingle A, Duran N, Galdiero S, Galdiero M. Broad spectrum bioactivities of silver nanoparticles: the emerging trends and future prospects. Appl Microbiol Biotechnol. 2014;98:19511961. doi:10.1007/s00253-013-5473-x
International Journal of Nanomedicine

\section{Publish your work in this journal}

The International Journal of Nanomedicine is an international, peerreviewed journal focusing on the application of nanotechnology in diagnostics, therapeutics, and drug delivery systems throughout the biomedical field. This journal is indexed on PubMed Central, MedLine, CAS, SciSearch ${ }^{\mathbb{R}}$, Current Contents ${ }^{\mathbb{R}} /$ Clinical Medicine,

\section{Dovepress}

Journal Citation Reports/Science Edition, EMBase, Scopus and the Elsevier Bibliographic databases. The manuscript management system is completely online and includes a very quick and fair peer-review system, which is all easy to use. Visit http://www.dovepress.com/ testimonials.php to read real quotes from published authors. 